\title{
THE EFFECTS OF MACROECONOMIC CONDITIONS AT GRADUATION ON OVEREDUCATION*
}

\author{
Fraser Summerfield ${ }^{\dagger} \quad$ Ioannis Theodossiou ${ }^{\ddagger}$
}

January 25, 2017

\begin{abstract}
This paper shows that unfavourable economic conditions at graduation decrease the likelihood of a good job-worker match over a worker's subsequent career. Mismatch is quantified in terms of overeducation by both industry and occupation. The German Socio-Economic Panel and region-level unemployment rates from 1994-2012 are used. Instrumental Variables estimates account for endogenous graduation timing. A single percentage point increase in regional unemployment causes an increase in the probability of overeducation of 1.6-1.7 percentage points for university graduates. Effects for technical tertiary education and apprenticeship graduates are smaller. Labour market entry conditions affect workers for up to 9 years after graduation. (JEL: J23, J22, E32, I23)
\end{abstract}

${ }^{*}$ The authors are grateful to the editor, two anonymous referees of this journal and seminar participants at the University of Aberdeen and the CEDEFOP/IZA workshop on skills and skill mismatch for very helpful comments and suggestions.

${ }^{\dagger}$ Department of Economics, Lakehead University. 955 Oliver Road, Thunder Bay ON, P7B 5E1 Canada. Contact information for Fraser Summerfield (Corresponding author), email: fraser.summerfield@ lakeheadu.ca, telephone: +1 8073438919.

${ }^{\ddagger}$ Business School and Centre for European Labour Market Research (CELMR), University of Aberdeen. Dunbar Street, Aberdeen AB24 3QY, United Kingdom. Contact information for Ioannis Theodossiou, email: theod@abdn.ac.uk, telephone: +44 1224272183. 


\section{INTRODUCTION}

Research has identified the importance that initial career conditions, such as graduation during recessions, have on workers' long-term earning capability (Kahn, 2010; Oreopoulos et al., 2012). Yet, "the literature on the career effects of entry conditions is still sparse on underlying mechanisms" despite a growing body of evidence across many countries (Altonji et al., 2016). One potential underlying mechanism through which entry conditions affect the worker's subsequent career appears to be related to the quality of the match between the worker and the job performed. Measures of vertical mismatch such as overeducation are likely to increase in slack labour markets where competition for jobs is fierce. The literature also shows that job match quality varies with the business cycle and that poor job matches (overeducation in particular) are linked to low pay. The above literature implies that initial conditions have lasting effects on job match quality. Yet, an explicit link to overeducation has not been made. Indeed, Hagedorn and Manovskii (2013) show that past aggregate labour market states explain current wages only because the latter are correlated with workers' job match quality and Liu et al. (2016) show that initial labour market conditions affect the likelihood of workers finding a job in an industry well-matched to their field of study.

This paper adds to this literature by assessing the effects of past labour market conditions on the quality of the worker-to-job education match, more specifically 
on overeducation. Using data from the German Socio-Economic Panel (GSOEP) for the years 1994-2012, workers with post-secondary education are linked to the regional (Bundesland) unemployment rates they faced when graduating from their highest level of education. Regional unemployment rates are deemed to best reflect the labour market conditions facing graduates in view of the fact that regional labour mobility in Germany is relatively low. ${ }^{1}$ Overeducation is measured by the difference between the individual's years of education and the median years of education observed in their occupation or industry. An Instrumental Variables (IV) estimation strategy, similar to Kahn (2010), is used to overcome the potential endogeneity of graduation timing. Findings show that a one percentage point increase in the regional unemployment rate facing new graduates causes a 1.0-1.4 percentage point increase in the probability of overeducation. This impact is strongest among university graduates where occupation and industry-based overeducation measures increase by 1.6 and 1.7 percentage points, respectively. When impacts are measured at 3-year intervals over the career, initial conditions appear to have scarring effects in terms of increased overeducation for up to 9 years.

Overeducation is an important labour market indicator since it implies the underutilisation of workers' skills and subsequent earnings losses. The economic sig-

\footnotetext{
${ }^{1}$ Labour mobility is much lower in Germany than in other countries such as the US. Only $3 \%$ of all observations in the data studied amount to workers who have switched federal state since their graduation date.
} 
nificance of these costs depends on whether or not overeducation is temporary. Chassamboulli (2011) suggests that workers may accept a bad match rather than unemployment. Yet, the duration analysis of Baert et al. (2013) shows that workers temporarily accepting poor quality matches may prolong the wait for a more appropriate match. Furthermore, Rubb (2003a) shows that in the 1990s only one in five overeducated workers moved to a better match within a year and Liu et al. (2016) show significant persistence in wage losses from mismatch between field of study and industry. Both latter studies imply that overeducation is a longer-term phenomenon. As such, understanding the mechanisms driving persistent career losses is essential to the design of government employment programs targeting the employability of young workers. Given the persistently high youth unemployment rates, which ranged from $16 \%$ in the US to over $50 \%$ in Spain and Greece during 2012 (OECD, 2013), it is important for policy makers to gain knowledge on the mechanisms through which overeducation causes further disadvantage among young labour market entrants. Furthermore, in the aggregate, overeducation affects productivity and economic output. The extent of foregone productivity may be substantial in Germany and other developed countries. Using a measure that compares individual years of education to the median for their occupation (industry), this paper finds that $24 \%$ (35\%) of German workers with higher education were overeducated during the years 1994-2012. This is in line with the overall incidence among 
European countries of $29 \%$, found in the meta-analysis of Leuven and Oosterbeek (2011). To the extent that initial conditions have lasting effects, the recovery phase should also be affected by overeducation. Workers that graduate during a recession may find themselves overeducated and embarking on career paths with limited scope for the patterns of cyclical occupational upgrading as described by Devereux (2002).

Germany has a particularly well-developed apprenticeship system, which causes it to differ from other countries like the US or the UK where apprenticeships are not well integrated into the educational system and where the majority of higher education is at the university level. In this context a greater share of the documented overeducation may be attributed to labour market conditions. Furthermore, German university graduates tend to be older than US or UK graduates: the modal graduation age is 27 in Germany compared to 22 in the US (Kahn, 2010). Hence, although scarring effects due to graduating in recession among the youth have been demonstrated in the past (Burgess et al., 2003; Ellwood, 1982) the current results provide evidence that scarring effects are also observed among individuals with more life experience. These findings may help to distinguish labour market effects from age effects.

The rest of the paper proceeds as follows. Section II outlines the related literature. In Section III the GSOEP data and measures of overeducation are described. 
Section IV.1 outlines the identification strategy and discusses the instrumental variables. Baseline OLS results in Section V.1 that link graduation conditions to overeducation are complemented with causal IV estimates in Section V.2. Results are provided separately by education type in Section V.3, demonstrating that effects are strongest for university graduates. Section V.4 examines the persistence of scarring effects at three-year intervals beyond initial graduation. Section VI concludes.

\section{LITERATURE REVIEW}

This paper builds on the literature linking labour market entry conditions to wage outcomes. Raaum and Røed (2006) found that past labour market conditions affect future employment. Beaudry and DiNardo (1991) and McDonald and Worswick (1999) have also showed that initial labour market conditions affect withinjob earnings growth because of imperfect mobility. More recently, it has been shown that individuals who graduate or enter the labour market when conditions are adverse experience large and persistent negative effects during their subsequent careers. The influence of labour market entry conditions on worker wages has been documented for the US (Altonji et al., 2016; Bowlus and Liu, 2003; Hershbein, 2012; Kahn, 2010; Oyer, 2006), Canada (Oreopoulos et al., 2012), Austria (Brunner and Kuhn, 2014), Japan (Kondo, 2007; Genda et al., 2010), and Germany (Stevens, 2007). Finally, Frühwirth-Schnatter et al. (2012) has explicitly linked 
more favourable labour market entry conditions to better long-run wage trajectories.

Furthermore, a separate literature including Barlevy (2002); Bowlus (1995); Mustre-del-Río (2014) shows that matches formed in a downturn tend to be of lower quality compared to these formed during an upswing. This is an outcome of job search in a slack labour market. With a larger pool of applicants, all job offers including good matches are less common (Albrecht and Vroman, 2002; Charlot et al., 2005; Moscarini, 2001; Wong, 2003). As a result, job search is more costly and workers are more willing to accept jobs for which they are overqualified. Whereas the above literature examines the effect of labour market conditions on the outcome of the worker's current job search process, this study investigates the effects of the labour market conditions at the start of the worker's career on his or her subsequent job matches. In addition, whereas the above studies use responses about the desire to switch jobs or recorded job durations as measures of mismatch, this paper uses overeducation as a measure of mismatch.

Studies that use overeducation as a measure of job match quality have produced contradictory results. For instance, Rubb (2014) finds that unemployment increases overeducation when controlling for self-selection. Yet, Büchel and Van Ham (2003) who also control for self-selection and the meta-analysis study of Groot and Maassen van den Brink (2000), report an insignificant relationship between unem- 
ployment and overeducation. Notwithstanding the importance of unemployment on the search process, which motivates this paper, the current study focuses on the effect of labour market conditions at the time of graduation on subsequent job matches during a worker's career. This is a distinct approach from papers that examine the contribution of contemporaneous unemployment rates to overeducation (Croce and Ghignoni, 2012; McGuinness et al., 2015).

Although the literature has suggested that wage penalties may be partly due to an increased propensity to accept jobs in low paying firms or occupations (Kahn, 2010; Kahn and McEntarfer, 2014; Speer, 2016), there has been far less attention paid to the quality of the match between a worker and their job. The exceptions are Verhaest and Van der Velden (2013) who demonstrate a cross-country correlation between the output gap and overeducation among workers in their first job and Liu et al. (2016) who show that initial labour market conditions affect Norwegian workers' chances of finding a job in an industry that best suits the their field of study. Interestingly, Liu et al. (2016) find that mismatch between field of study and industry can explain most of the long-term wage penalties associated with graduating during a recession.

The current paper differs from the papers above in some crucial respects; First, Verhaest and Van der Velden (2013) utilise a single cohort of graduates facing only cross-sectional differences in labour market conditions, whereas this study includes 
graduates entering the labour market during troughs and peaks of several business cycles in Germany from 1994 to 2012. Second, the current analysis utilises IV techniques in order to deal with the endogeneity of graduation timing and thus provide estimates with a causal interpretation. This is important because workers of higher ability may purposefully delay their graduation in order to avoid entering the labour market during a recession. Wage differentials between overeducated and well-matched workers have been linked to unobserved factors including workers' literacy or specific components of skill (Boothby, 2002; Sohn, 2010) and unobserved innate ability (Iriondo and Pérez-Amal (2013), for the EU, and Tsai (2010), for the US), suggesting that overeducated individuals are of lower ability than their well-matched counterparts with similar qualifications.

The current paper also differs substantially from Liu et al. (2016) because of the measure of mismatch. Their study uses a so-called "horizontal mismatch" measure, which compares the field of study of a worker to the most common fields of study among other workers in a given industry. This type of measure is informative regarding whether workers possess the industry-specific skills needed for their jobs. By contrast, the current paper uses overeducation, which is considered a "vertical mismatch" measure because it compares the quantity of schooling among workers within an occupation or industry. The current analysis is more likely to reflect mismatches in general human capital. This distinction is also important because 
horizontal measures of mismatch have generally not been linked to wage penalties to the same extent as measures of "vertical mismatch" (Eymann and Schweri, 2015; McGuinness and Sloane, 2011; Verhaest et al., 2015). A notable exception to this is Liu et al. (2016). Instead, the vertical measures used in the current analysis have been shown to have important consequences for worker wages in a separate literature surveyed by Leuven and Oosterbeek (2011); McGuinness (2006); Rubb (2003b); Groot and Maassen van den Brink (2000).

There is a particular need for clarification on the relationship between initial labour market conditions and measures of mismatch because existing studies provide somewhat contradictory evidence. For example, Bowlus (1995) uses long job tenure as a measure of a good job match. Yet, the findings of Kahn (2010) suggest that workers graduating during a recession and experiencing scarring effects tend to have longer job tenure. Similarly, Altonji et al. (2016) find that labour market entry conditions affect wages but not horizontal measures of match quality, which would seem to contradict the findings of Liu et al. (2016).

\section{DATA}

This paper uses data from the GSOEP for the years 1994-2012. The GSOEP is a nationally representative dataset with a wealth of detail on workers and their job characteristics. Using information on the timing and location of graduation, as well 
as detailed histories of schooling spells, indicators are constructed to identify the labour markets into which workers graduate. This initial labour market information is matched with the region-level unemployment rates for the civilian population (excluding entrepreneurs) provided by the German statistical agency Statistisches Bundesamt. ${ }^{2}$ The analysis is restricted to workers graduating from post-secondary education after 1994 because this is the extent of the availability of regional-level unemployment rates. ${ }^{3}$ Indicators are available for three streams of post-secondary education: university, "other" tertiary education (which encompasses technical training such as teacher education and some medical fields) and apprenticeship. Since some workers graduate from more than one level of education, the date of graduation from the highest level of education is the assigned graduation date in this study. ${ }^{4}$ Summary statistics are presented in Table 1 . The average worker observed in the data is age 28 with just under 14 years of education and about 5 years of work experience. ${ }^{5}$ The main estimation sample has 13,563 observations representing 2,421 workers.

\footnotetext{
${ }^{2}$ The authors thank Michael Stops at IAB for assistance locating these data.

${ }^{3}$ Results were also tested for robustness by generating unemployment rates directly from the GSOEP data since 1990, when data collection began for the former East German regions. The findings are robust. These results are not presented here but they are available from the authors on request.

${ }^{4}$ For example, an apprenticeship graduate would be linked to the graduation date of their apprenticeship program thereafter, until such time as they graduate university in which case they would be associated with the new graduation date. However, a university graduate who returns to study in an apprenticeship program would continue to be associated with their university graduation date.

${ }^{5}$ On average these workers have about 4 years of tenure in the current job and about $2 \%$ are in their first ever job.
} 
The overeducation measures in this paper use information from the education distribution of employed workers in the sample to define the "required" or appropriate level of education. These overeducation measures therefore reflect the current position of workers in the education distribution within occupation or industry in the year of observation. Thus these measures implicitly account for time trends in various occupational assignments. The impact from initial labour market conditions on the worker's relative job match can be interpreted as the long lasting effects of low economic activity on workers' labour market performance.

Overeducation, or education mismatch, is measured in several ways in this study. The main results are derived using two binary measures of overeducation. These measures follow Verdugo and Verdugo (1989) and are prevalent in the overeducation literature. Workers are assigned to the overeducated group if their years of education exceed the median years of education among workers in their occupation or industry by more than a standard deviation. ${ }^{6}$ The median (or "required" level of education) is measured within 4-digit ISCO occupation codes and 2-digit NACE industry codes in each year. ${ }^{7}$ Groups with fewer than 10 observations are excluded

\footnotetext{
${ }^{6}$ Measures using the mean and the mode, instead of the median, provided similar results. Robustness checks are provided in the Appendix.

${ }^{7}$ Overeducation within an occupation is a more straightforward concept than overeducation within an industry. There are very few studies on the relationship of industry and overeducation (e.g. Tarvid (2015)). The industry measure may still provide an important robustness check for the occupation measure and in the context of this paper it may also be informative in its own right. Assuming that production processes do not change over the business cycle, an increase in the education of workers relative to the industry median reflects a change in the type of worker hired and thus may reflect overeducation. Appendix Table A1 confirms this intuition by demonstrating a high correlation between the occupation- and industry-based measures of overeducation.
} 
because the required level of education generated from such small samples is unlikely to be representative. Because industry is measured at the 2-digit level, almost all groups are large enough to establish a required education level. Only 31 worker observations are excluded from the sample. In the case of 4-digit occupations 559 observations are excluded, but this was found not to affect the main results. ${ }^{8}$ Appendix Table A2 shows that the share of overeducated workers for their occupation is not statistically different between the samples that do and do not include these additional observations.

The prevalence of overeducated workers in the German labour force is also demonstrated in Table 1. Approximately $24 \%$ of workers in the sample are overeducated according to the occupation measure and $35 \%$ are overeducated according to the industry measure. These shares are higher than those reported in Daly et al. (2000) and Bauer (2002) because the analysis focuses on higher-education graduates. ${ }^{9}$ For both occupation and industry, the difference between actual and required education in years is also measured with a continuous variable. These alternative measures give a sense of the magnitude of overeducation and may help to capture any effects that do not meet the threshold set in the binary measure. The average

\footnotetext{
${ }^{8}$ Estimates that evaluate these additional observations against the 3-digit occupation, or 1-digit industry median education were also generated. Results are very similar and are available from the authors upon request.

${ }^{9}$ Bauer (2002) finds $12 \%$ of men and $11 \%$ of women are overeducated using measures based on the mean education of worker groups. Daly et al. (2000) reports that $14 \%$ of men and $20 \%$ of women were overeducated in 1984 using a self-reported measure.
} 
difference between the occupation median education and a worker's own actual education is 0.74 years, whereas for the industry measure it is almost a year and a half.

This paper focuses on the effect that economic conditions at graduation have on the probability of someone being overeducated in subsequent employment. To demonstrate the importance of this type of mismatch relative to other measures, a subjective "horizontal" measure of job match quality from the GSOEP is also included. This binary indicator is based on whether individuals "work in the occupation for which they are trained." In the sample of higher education graduates, $79 \%$ of workers are well-matched according to this horizontal measure. ${ }^{10}$

The data suggest that those who graduated during a recession are, on average, more likely to be overeducated. Figure 1 plots the probability of overeducation by 4-digit occupation against the regional unemployment rate at graduation. Shares of workers that are overeducated at every value of the unemployment rate are generated from the data. A local moving average fitted through the scatterplot demonstrates a positive and significant relationship between initial labour market conditions and overeducation rates. Figure 2 shows a similar, although less striking, relationship for overeducation rates defined within 2-digit industries. It is also in-

\footnotetext{
${ }^{10}$ Other dimensions of mismatch may also be interesting including mismatches across college major or other definitions of skill (Allen and van der Velden, 2001; Robst, 1995). However, an extended analysis is beyond the scope of the current paper.
} 
formative to examine overeducation rates in a way that accounts for the uneven grouping of individuals across unemployment rates in the sample. Table 2 provides the shares of workers who are mismatched across graduation unemployment rate groups of similar sample sizes. Workers have an overeducation rate of approximately $18 \%$ for their occupation if they entered the labour market during the most favourable times (when the regional unemployment rate was less than 6\%). The share of overeducated rises with the unemployment rates reaching $30 \%$ for those who graduated in labour markets with state-level unemployment rates in the range of $11-15 \%$. Similar results are found for the industry measure where overeducation rates range from about $27 \%$ to almost $42 \%$, respectively. ${ }^{11}$ Interestingly, it does not appear that the likelihood of working in the occupation one is trained for, a horizontal measure of mismatch, has the same cyclical property found in the vertical overeducation measures. The relationship between horizontal and vertical measures is further examined in Appendix Table A1. The two measures are virtually uncorrelated. It also turns out that, unlike the vertical overeducation measures used in this study, the horizontal measure does not exhibit cyclicality. This suggests that the macroeconomy tends to affect vertical rather than horizontal mismatch, at least in the case of Germany.

\footnotetext{
${ }^{11}$ The cyclical pattern does not hold for the group with unemployment rates above $15 \%$. Observations with these unemployment rates represent mainly those workers graduating in the former Eastern Germany's poorest regions where workers may graduate into unemployment rather than into employment associated with overeducation.
} 


\section{EMPIRICAL APPROACH}

The empirical analysis is based on a parsimonious specification that is designed to separate the effects of initial labour market conditions from the effects of a worker's human capital. For each of the overeducation measures $(O E)$, the baseline equation (1) is estimated using the linear probability model. ${ }^{12}$

$$
O E_{i r t}=\alpha+X_{i r t}^{\prime} \beta+\gamma U_{r t-h}+\delta_{r}+\tau_{t}+\epsilon_{i r t}
$$

The coefficient $\gamma$ is an estimate of the relationship between region-level unemployment rates $(U)$, in the region of gradation (r) and at the time of graduation $(t-h)$, on the overeducation measure $(O E)$ of worker $i$ in period $t$. Estimates are weighted using the enumeration weights provided in the GSOEP to give representative results for the German population.

Labour market conditions vary at the regional level and by the time of graduation. Thus, the empirical model relies on regional fixed-effects to capture the group structure of the standard errors. However, serial correlation within regions is still a concern (Bertrand et al., 2004). Therefore, standard errors are clustered on the region of graduation. Unfortunately, it is also true that cluster-robust inference may lead to over rejection of the null in t-tests when the number of clusters

\footnotetext{
${ }^{12}$ The linear probability model is chosen over the probit or logit analysis because it permits more careful inference with wild cluster-robust inference. Probit models give similar results.
} 
is low (Cameron and Miller, 2015). In the case of Germany there are 16 federal regions, which fall between the potential thresholds of 42 suggested by Moulton (1986) and 10 suggested by Angrist and Pischke (2009). ${ }^{13}$ The wild-cluster bootstrap of Cameron et al. (2008) is therefore employed to provide robust inference for our variable of interest.

The model also includes the covariate vector $(X)$. This vector contains dummy variables for the highest completed education stream (university, other tertiary and apprenticeship), gender, marital status, and German nationality. These demographic variables are usually included in wage regressions and they are expected to play a role in employment possibilities and therefore the probability of overeducation. Continuous controls for age and full-time work experience measured in years, as well as their quadratics, are included. Region of graduation dummy variables $(\delta)$ and year dummy variables $(\tau)$ are also included. Approximately 3\% of the individuals in the sample have relocated since graduation to a different region. ${ }^{14} \mathrm{~A}$ dummy variable that captures geographic mobility since graduation is also included to account for the possibility that geographic mobility contributes to the likelihood of overeducation. This may be important when considering regional labour markets

\footnotetext{
${ }^{13}$ It should be noted, however, that cluster-robust standard errors from popular statistics packages such as Stata might still behave well with less than 10 clusters. (Angrist and Pischke (2009) citing Hansen (2007)).

${ }^{14}$ Regional mobility in Germany is also found to be low in other studies. Arntz (2005) finds that only $7 \%$ of unemployed workers relocate more than $80 \mathrm{~km}$ to take up a new job and, using the GSOEP, Resuchke (2011) finds that only $10 \%$ of all relocation events cross regional borders.
} 
if those of higher ability, for example, are more likely to avoid overeducation by relocating to a neighbouring region.

\section{IV.1 Identification}

Identifying the causal impact of region-level unemployment rates requires that unemployment rates are exogenous. Certainly, macroeconomic conditions at the regional level cannot be meaningfully influenced by the decisions of any one individual worker. However, endogeneity could be an issue because of graduation location or timing. Individuals may attempt to time their graduation to coincide with improved labour market conditions. This is especially true among university graduates in Germany since many degree programs do not have fixed timelines and tuition fees are relatively low. Any bias might therefore be expected to be most significant for university graduates. Scrupulous students may also choose to attend tertiary education or enrol in apprenticeship programs in regions where jobs are more prevalent. This might be particularly true in apprenticeship programs where connections are made with future employers.

The data suggest that some workers do delay their graduation. Among graduates with university education, $25 \%$ of the sample graduate beyond age 29 . The equivalent statistics for tertiary education and apprenticeships occur at ages 23 and 21, respectively. The modal graduation ages are 27 for university, 21 for other tertiary 
schooling and 20 for apprenticeships. The share of workers who switch region since age 14 is low at only $3 \%$ of the sample. Results addressing endogeneity with IV estimates are presented in Section V.2. The IV approach used in this paper exploits exogenous variation in labour market conditions that originates from the accident of birth and therefore sidesteps issues of endogenous gradation timing. However, these results suggest that endogeneity bias in the OLS estimates is negligible.

\section{RESULTS}

\section{V.1 Baseline Specification}

Regional unemployment rates at the time of graduation have positive and significant effects on the likelihood that a worker is overqualified. Table 3 presents OLS estimates of equation (1) using various outcome measures. The graduation date and location from the highest level of completed education is used in these results. Estimates are presented with indicators for statistical significance from cluster-robust standard errors, and wild-bootstrap p-values are included at the bottom of the table. Only those results that are significant with both methods of inference are discussed.

Columns 1 and 2 show the effects of a downturn on the binary measures of overeducation within occupation and industry, respectively. A single percentage point increase in the regional unemployment rate at labour market entry leads to a 1.2 percentage point increase in the likelihood of overeducation within a worker's 
occupation. Given that $18 \%$ of all workers in the GSOEP data are overeducated, this is a significant result. A recession which increases regional unemployment by 4 percentage points could be expected to increase the share of overqualified workers in the labour force by 4.8 percentage points, which would represent an increase of about $25 \%$ in the average overeducation rate. Columns 3 and 4 examine the difference between actual education and required education arising from labour market entry conditions. These linear measures provide insight about the extent of overeducation among workers as a result of macroeconomic conditions. Column 4 shows that a single percentage point increase in the region unemployment rate at labour market entry increases the amount by which actual education exceeds required education by about 0.7 years. ${ }^{15}$

The sizes of the coefficients in this study are somewhat lower relative to earlier studies. For example, Liu et al. (2016) find that a three percentage point increase in unemployment rates leads to a $30 \%$ increase in mismatch. However, the results are not directly comparable because Liu et al. (2016) measure mismatch by comparing a worker's industry to their field of education. The relatively small effects found here might be explained by the fact that the incidence of mismatch is considered across a worker's entire career, as observed in the data. Nevertheless, the

\footnotetext{
15 Estimates were also calculated where required education was defined by both occupation and industry. Estimates are insignificant due to reduced sample sizes, although coefficients are broadly similar. These results are available from the authors upon request.
} 
current findings are in line in terms of magnitude with predictions from a structural model of the Canadian economy. Summerfield (2016) finds that a single percentage point increase in regional unemployment at the time of job creation leads to a 3 percentage point increase in the probability of an individual being overeducated.

The results above demonstrate that overeducation, a measure of vertical mismatch, responds to labour market entry conditions. To investigate whether entry conditions also affect horizontal mismatch, a GSOEP measure of specific job match is also used. Whereas the overeducation measures may capture mismatch in general transferrable skill, this alternative measure may capture mismatch between training and occupation or mismatch across educational fields. Estimates in column 5 indicate that labour market entry conditions do not affect the likelihood of a worker being employed in an occupation that they are trained for. This result differs from Liu et al. (2016) who do find some evidence of horizontal mismatch between field of study and industry. The very low correlation between vertical and horizontal measures used in this paper (Appendix Table A1) suggest that horizontal and vertical mismatch may arise for separate reasons. Overeducation, or vertical mismatch, appears to be the more relevant measure for cyclical mismatch in the labour market. Horizontal mismatch may reflect structural change that brings about changes in the demand for specific skills. However, the latter is not examined in this study. ${ }^{16}$ Ver-

\footnotetext{
${ }^{16}$ It should be noted that the GSOEP measure is subjective and therefore it may be noisier than the other measures used in this paper. Hence, this type of mismatch is not discussed further.
} 
tical mismatch is indicative of a worker's position in the hierarchy of general skills and it is expected to vary with the business cycle.

The vector of estimates $\beta$ is informative regarding factors other than macroeconomic conditions that contribute to overeducation. University graduates in general appear more likely to be overeducated compared to those with "other" tertiary education, although this estimate is insignificant for the occupation measure. In general, apprenticeship graduates are as likely to be overeducated as workers that have completed other tertiary education. Overeducation also increases with age following a quadratic path and decreases with years of work experience. The latter result implies that more experienced workers rely on their experience and on-the-job learning as a source of human capital rather than to formal education. An alternative interpretation is that workers initially accept an overeducated role, and later are promoted to a role commensurate with their skills. ${ }^{17}$ The positive effect of age on overeducation may reflect the depreciation of human capital. With the advent and proliferation of computers and technology in the workplace, older workers may find themselves relegated to jobs which typically attract less-educated workers.

\footnotetext{
${ }^{17}$ The authors thank an anonymous referee of this journal for fruitful suggestions relating to this interpretation.
} 


\section{V.2 IV Estimates and Endogeneity Bias}

Although individual workers cannot reasonably be expected to affect the macroeconomy, they may be able to control when and where they graduate. ${ }^{18}$ Therefore, addressing potential endogeneity bias is critical for the credibility of the findings. Unemployment rates at the actual graduation location and time are instrumented with regional unemployment rates in the location where a worker lived at age 14 , and at the modal graduation time for others within the same age cohort and education stream. This approach is akin to instrumenting actual graduation with the graduation path an individual would have followed if they had not moved location or delayed their program completion. Three separate instruments are created so that one represents each of the three higher education streams analysed in this paper. These instruments provide a source of exogenous variation in labour market entry conditions. At age 14 it is likely that individuals are living in the family household, yet it is unlikely that their decisions affect the household's location. Economic conditions at the modal age of graduation are also not within the realm of control of an individual. Therefore, the instrument exploits changes in the regional unemployment rate that new graduates face as a result of the accident of their birth. Following Kahn (2010) experience is removed from the specification, because experience is

\footnotetext{
${ }^{18}$ Recessions have also been linked to the decision to enrol in post-secondary education (Alessandrini et al., 2015; Betts and McFarland, 1995; Dellas and Sakellaris, 2003). Although this is an interesting issue, it is beyond the focus of this study.
} 
also endogenous if workers delay (or accelerate) their education.

After controlling for endogeneity bias, the estimated effects of entry conditions change little relative to the OLS estimates. Table 4 presents IV estimates that correspond to the OLS estimates in Table 3. The effects are almost identical. A single percentage point increase in the regional unemployment rate at graduation leads to an increase in the probability of being overeducated by approximately 1.4 percentage points for the occupation measure and a single percentage point for the industry measure. The linear distance measures are also positive and significant. As with all other results, there is no meaningful effect on the horizontal measure of mismatch. Similar IV and OLS estimates are justified in view of the low incidence of geographic relocation observed in the data. The apparent delay in graduation among groups of workers may simply reflect the education program duration.

The bottom panel of Table 4 summarises the first stage results. All three of the instruments correlate positively and strongly with the endogenous unemployment rate at graduation. Indeed, it is reasonable that the most common graduation date and location for an individual is highly correlated with his or her actual graduation date and location. Multivariate F-tests (Angrist and Pischke, 2009) show that the null hypothesis of weak instruments is rejected at the $1 \%$ level in all cases. Because there are three instruments, it is also possible to test against a null-hypothesis of exogenous instruments using the Sargan-Hansen overidentifica- 
tion test. The test-statistic is insignificant across all three specifications indicating that the null-hypothesis cannot be rejected, the expected result given the intuition behind these instruments.

\section{V.3 Education Types and Overeducation}

Overeducation may be more likely for graduates of certain education streams. University graduates may accept employment opportunities that do not strictly require university, while those without university education are less likely to receive employment offers for positions typically filled with university graduates. This section provides estimates using an alternative specification that estimates the effect of graduation conditions separately by education stream.

$$
O E_{i r t}=\alpha+X_{i r t}^{\prime} \beta+U_{r t-h} \times\left(\gamma^{U N} E_{i r t}^{U N}+\gamma^{T E} E_{i r t}^{T E}+\gamma^{A P} E_{i r t}^{A P}\right)+\delta_{r}+\tau_{t}+\epsilon_{i r t}
$$

Graduation unemployment rates are interacted with indicators $(E)$ for university (UN), other tertiary (TE) and apprenticeship (AP) graduation, so that each individual is assigned a value only for the variable corresponding to their own highest level of education. This specification allows one to investigate whether initial labour market conditions affect certain types of graduates in a different way compared to others. Added flexibility by education type may be particularly important in the case of Germany because it has a well-developed apprenticeship system. Technical and theoretical education may provide workers with more specific and more 
general human capital, respectively. If this is the case, economic conditions may have different effects on individuals with different educational attainment. For example, a university educated individual may be able to find a job for which she or he is overqualified if her/his general skills are productive in other fields of work, whereas an apprentice may be more likely to suffer unemployment if her/his skills are not transferrable to other, perhaps less suitable, jobs.

Table 5 shows that the effects above are predominantly driven by the experience of university graduates. A single percentage point increase in the regional unemployment rate would lead to a 1.6 percentage point increase in the probability of one's overeducation within his/her occupation. Within one's industry, the impact is slightly higher at 1.7 percentage points. These results are in line with intuition if university education is expected to develop a more general and transferrable form of human capital. However, specific human capital that characterises apprenticeship and other tertiary education has been shown to vary with industry (Neal, 1995), and/or occupation (Kambourov and Manovskii, 2009). There is also some evidence that apprenticeship graduates may be affected by entry conditions. However, this effect is found only for the occupation based measure.

The instruments are highly significant in the each of the three first stages. ${ }^{19}$

\footnotetext{
${ }^{19}$ Only the corresponding education type instrument is shown. However all three instruments are part of all three first stages. In all cases, among the three, only the instrumental variable coinciding with the schooling stream of interest turns out to be statistically significant in the first stage.
} 
Coefficients are large and significant and the multivariate F-tests suggest that the instruments are not weak. Because there are three instruments and three endogenous unemployment rates, these models are just-identified and it is not possible to test overidentifying restrictions.

The IV estimates show that the effects of schooling type and age are similar with respect to the initial specification and, in addition, the coefficient for the married dummy variable is now significant. The dummy variable that indicates residence in a different region than the region of graduation becomes significant. Those who re-locate to other regions appear to be more likely to be overqualified in their job. The coefficient for region switch is likely to capture those who move for reasons such as the career of a spouse or a better wage or working conditions. Workers who move to a new region may have less developed professional networks and might be expected to start lower on the career ladder.

As a robustness test, two alternative measures of overeducation are used. First, estimates corresponding to columns 1-4 in Table 5, that evaluate a worker's overeducation based on the mean education within the same year and occupation or industry, are presented in Appendix Table A3. The magnitude of estimated impacts is very similar to the earlier results. Second, in Appendix Table A4, results are presented that evaluate worker education against the yearly mode for their occupation and industry. In this measure a standard deviation is less intuitive and so work- 
ers with years of education exceeding the mode are considered overeducated. The results are again similar to the earlier results except that the effect of university graduates in Column 1 turns out to be statistically insignificant. ${ }^{20}$

\section{V.4 Scarring Effects of Recessions on Job Matches}

The costs of overeducation for workers may depend on the length of time that workers remain "trapped" in jobs for which they are overqualified. The career path of young workers is often characterised by significant job mobility (Topel and Ward, 1992). Job-to-job transitions provide important sources of wage growth through occupational upgrading (Devereux, 2002). Temporary overeducation, as part of a career path that is optimal over the life cycle, might not be viewed as a negative situation. Frei and Sousa-Poza (2012), for example, find that half of overqualified Swiss workers find a suitable match within one year. Evidence that job match quality is procyclical also suggests that overeducated workers might move to better matches when conditions improve (Bowlus, 1995; Carrillo-Tudela et al., 2016; Devereux, 2000, 2004; Moscarini and Vella, 2008). Still other findings suggest that Flemish (Baert et al., 2013), and Norwegian (Liu et al., 2016) workers may get "trapped" in poor matches. Overskilling has been shown to be self-perpetuating in Australian data (Mavromaras and McGuinness, 2012) Frühwirth-Schnatter et al. (2012) show

\footnotetext{
${ }^{20}$ In many cases there is a tie for modal years of schooling, more so within a yearly 4-digit occupation category than a 2-digit industry category. In this case the higher value is used in order to obtain conservative estimates. This may help to explain a smaller impact for occupation measures while industry measures remain similar to Table 5 .
} 
that adverse entry conditions cause unfavourable income trajectories.

This section presents estimates showing that scarring effect of labour market entry conditions on job match quality lasts up to 9 years after graduation. The equation (3) below builds on the baseline specification:

$$
O E_{i r t}=\alpha+X_{i r t}^{\prime} \beta+\gamma U_{r t-h}+Z_{i r t}^{\prime} \pi+\left(U_{r t-h} \times Z_{i r t}\right)^{\prime} \rho+\delta_{r}+\tau_{t}+\epsilon_{i r t}
$$

The vector $Z$, which is comprised of dummy variables for the year of graduation, and 3-year groups for years thereafter, is included along with its interaction with initial conditions. These variables are in lieu of the continuous measures of experience. The dummy variables continue to allow for non-linear effects related to experience while the interaction terms allow the effect of entry conditions to vary across the experience dimension.

Table 6 presents the marginal effect of labour market entry conditions $(U)$ on overeducation $(O E)$, evaluated at the year of graduation and three year intervals thereafter. The top panel includes graduation from all types of education. Estimates for the probability of overeducation by occupation suggest that labour market entry conditions have persistent effects. The marginal effects are significant and positive up to 9 years after graduation. It should be noted that estimates are imprecise for the marginal effects beyond 9 years and so there is no evidence that initial effect disappears, although it is also not possible to reject the possibility of no effect. This 9-year effect is similar in duration to the wage penalty scarring effects reported in 
Oreopoulos et al. (2012) and Liu et al. (2016). The effects are similar when defining overeducation by industry, also lasting for 6 years. The continuous measures capturing the linear distance between actual and required education for an industry suggest slightly longer persistence. This result shows that some important variation in overeducation occurs late in the career even if this variation is insufficient to meet the threshold of the binary measures

Furthermore, it is important to disentangle the effect that initial conditions have on future overeducation due to initial-job mismatch from the effect that they have on subsequent overeducation through labour market experience scarring effects. In an attempt to shed some light in this issue, Appendix Table A5 presents auxiliary OLS results where there is a control capturing whether or not individuals were overeducated in their first job. These results suggest that initial-job mismatch plays an important role, increasing the probability of overeducation by 38 percentage points and 45 percentage points for occupation and industry measures, respectively. Yet, initial labour market conditions retain their positive and significant contribution to overeducation conditional on prior mismatch, implying the importance of the detrimental effect of slack labour market conditions on future overeducation over and above possible independent confounding effects of initial bad matches.

Since estimates by education type in Section V.3 suggest that the effect is strongest among university graduates, the bottom panel of Table 6 presents marginal effects 
for university graduates only. These results suggest that the negative impacts of graduating during a recession are stronger later in the careers of university graduates. One possible explanation of this finding may reflect the sorting mechanisms of the graduate employment labour markets. A large number of new graduates should be expected to be mismatched initially, regardless of labour market conditions, as career path jobs often involve on-the-job-training with lesser job titles and lower wages. ${ }^{21}$ Thus scarring effects may be masked in early job matches, only to become visible later on when these graduates experience delayed career advancement relative to their peers who graduated in better labour markets. Workers that find initial jobs in a recession may find limited opportunity in the future resulting from firms' unwillingness to invest in their workforce when facing uncertainty about future demand. It is also true that those graduates who do find a good match during a recession are more likely to work initially in temporary jobs and experience several early-career unemployment spells. Even if these early-career jobs appear as good matches, this job history is likely to be a negative signal to future employers and could adversely affect future job prospects and job matches.

Thus, the finding that the negative impacts of graduating during a recession are stronger later in the careers of university graduates is a significant result as it high-

\footnotetext{
${ }^{21}$ Devereux (2000) finds that some firms reassign workers to lower quality tasks (demote them) during recessions. However, this effect is unlikely to be widespread, especially in European labour markets, due to the strength of labour laws and collective agreements.
} 
lights the potential of serious career repercussions. ${ }^{22}$ The finding is also consistent with the result from Appendix Table A5, that labour market entry conditions affect overeducation conditional on the match quality in a workers first job. Plots of these marginal effects are presented in the Appendix Figures A1 and A2.

Table A6 in the Appendix includes an alternative set of estimations that address the historical path of labour market conditions faced by workers. This approach isolates the entry effect from the effects of exposure to subsequent labour market conditions. Control variables for the average regional unemployment rate at each of the time intervals are included in place of the time dummy variables following the approach of Oreopoulos et al. (2012). Estimation is repeated on a sub-sample of workers who do not switch regions and for whom these histories can be reliably generated. The coefficient estimates are remarkably similar in magnitude although the 3- and 9-year interaction effects are no longer significant.

Several of the measures of overeducation are insignificant or negative during the year of graduation. This implies that those workers who end up overeducated, select into these work arrangements after searching unsuccessfully for more suitable jobs. It is also interesting to note that the horizontal mismatch estimate, which captures the probability of employment in the occupation for which an individual is trained, is significant and negative in the year of graduation only. This suggests that the

\footnotetext{
${ }^{22}$ The authors thank an anonymous referee of this journal for drawing our attention to the significance of this finding.
} 
effect on horizontal mismatch is temporary and implies that workers accept jobs outside their field as a stopgap measure.

\section{CONCLUSIONS}

This paper examines the role of macroeconomic conditions at graduation, or first labour market entry, on the mismatch of workers throughout their careers. The mismatch is approximated with measures of overeducation that compare the educational attainment of workers to the median education within their occupation. Using an IV estimation to control for the potentially endogenous timing of graduation the paper shows that increases in regional level unemployment rates at graduation affect the future probability of overeducation, and hence mismatch.

The findings in this paper suggest that the costs of recessions may extend to the future career of the affected workers. Whereas there is a focus among policymakers on unemployment statistics, unfavourable labour market conditions are also costly for those who do find work. This paper also suggests that scarring effects are persistent because estimates of the probability of overeducation are not restricted to early career workers. Furthermore, the effects of initial labour market conditions may last up to 9 years after graduation. The duration of scarring effects suggested by these overeducation estimates is consistent with the duration of scarring effects on wages in the literature. This suggests that overeducation may help to explain 
why workers graduating in a recession earn lower wages for several years after they enter the labour market.

Therefore, the results in this paper suggest that time does not cure all evils. Although workers may be able to climb the ladder, switching to better jobs as times improve, many workers cannot overcome the initial scarring effect. Some workers may choose to remain mismatched after the recession if they have developed specific human capital that might be lost in transition to the "right" job. However, there may be scope for training and job-search assistance programs following recession periods to assist those who are better served by returning to occupations or industries where their education is fully utilised. These policies may benefit some more experienced workers as well as recent graduates.

This study finds scant evidence that horizontal mismatch responds to initial labour market conditions. Therefore, policy to improve job matching may be more effective if it is directed at workers with vertical mismatch. It appears that overeducation, that is an excess level of schooling, rather than mismatch across fields of study, is more likely to come about because of economic downturns. It is also more likely to have significant and lasting effects.

\section{References}

Albrecht, J. and S. Vroman (2002). A matching model with endogenous skill requirements. International Economic Review 43(1), 283-305. 
Alessandrini, D., S. Kosempel, and T. Stengos (2015). The business cycle human capital accumulation nexus and its effect on hours worked volatility. Journal of Economic Dynamics and Control 51, 356-377.

Allen, J. and R. van der Velden (2001). Educational mismatches versus skill mismatches: effects on wages, job satisfaction, and on-the-job search. Oxford Economics Papers 3, 434-452.

Altonji, J., L. Kahn, and J. Speer (2016). Cashier or consultant? Entry labor market conditions, field of study, and career success. In Labor Markets in the Aftermath of the Great Recession. NBER.

Angrist, J. D. and J. Pischke (2009). Mostly Harmless Econometrics: An Empiricist's Companion. Princeton University Press.

Arntz, M. (2005). The geographical mobility of unemployed workers: Evidence from West Germany. Discussion Paper 05-34, ZEW.

Baert, S., B. Cockx, and D. Verhaest (2013). Overeducation at the start of the career: stepping stone or trap? Labour Economics 25, 123-140.

Barlevy, G. (2002). The sullying effect of recessions. The Review of Economic Studies 69(1), 65-96.

Bauer, T. (2002). Educational mismatch and wages: a panel analysis. Economics of Education Review 21, 221-229.

Beaudry, P. and J. DiNardo (1991). The effect of implicit contracts on the movement of wages over the business cycle. Journal of Political Economy 99(4), 665-688.

Bertrand, M., E. Duflo, and S. Mullainathan (2004). How much should we trust differences-in-differences estimates? Quarterly Journal of Economics 119(1), $245-279$.

Betts, J. and L. McFarland (1995). Safe port in a storm: the impact of labor market conditions on community college enrollments. Journal of Human Resources 30, $741-765$.

Boothby, D. (2002). Literacy skills, occupational assignment and the returns to over- and under-education. Catalogue no. 89-552-MPE no.9, Statistics Canada and Human Resources Development Canada. 
Bowlus, A. and H. Liu (2003). The long-term effects of graduating from high school during a recession: Bad luck or forced opportunity. Working Paper 2003-7, CIBC Center for Human Capital and Productivity.

Bowlus, A. J. (1995). Matching workers and jobs: Cyclical fluctuations in match quality. Journal of Labor Economics 13(2), 335-350.

Brunner, B. and A. Kuhn (2014). The impact of labor market entry conditions on initial job assignment and wages. Journal of Population Economics 27(3), 705738.

Büchel, F. and M. Van Ham (2003). Overeducation, regional labor markets, and spatial flexibility. Journal of Urban Economics 53(3), 482-493.

Burgess, S., C. Propper, H. Rees, and A. Shearer (2003). The class of 1981: the effects of early career unemployment on subsequent unemployment experiences. Labour Economics 10(3), 291-309.

Cameron, A. C., J. B. Gelbach, and D. L. Miller (2008). Bootstrap-based improvements for inference with clustered errors. The Review of Economics and Statistics 90(3), 414-427.

Cameron, A. C. and D. L. Miller (2015). A practitioner's guide to cluster-robust inference. Journal of Human Resources 50(2), 317-372.

Carrillo-Tudela, C., B. Hobijn, P. She, and L. Visschers (2016). The extent and cyclicality of career changes: evidence for the UK. European Economic Review 84, 18-41.

Charlot, O., B. Decreuse, and P. Granier (2005). Adaptability, productivity, and educational incentives in a matching model. European Economic Review 49, $1007-1032$.

Chassamboulli, A. (2011). Cyclical upgrading of labor and employment differences across skill groups. The B.E. Journal of Macroeconomics 11, 1-42.

Croce, G. and E. Ghignoni (2012). Demand and supply of skilled labour and overeducation in Europe: A country-level analysis. Comparative Economic Studies 51, 413-439.

Daly, M. C., F. Büchel, and G. J. Duncan (2000). Premiums and penalties for surplus and deficit education: Evidence from the United States and Germany. Economics of Education Review 19, 169-178. 
Dellas, H. and P. Sakellaris (2003). On the cyclicality of schooling: theory and evidence. Oxford Economic Papers 55, 48-172.

Devereux, P. (2000). Task assignment over the business cycle. Journal of Labor Economics 18, 98-124.

Devereux, P. (2002). Occupational upgrading and the business cycle. Labour 16(3), 423-452.

Devereux, P. (2004). Cyclical quality adjustment in the labor market. Southern Economic Journal 70(3), 600-615.

Ellwood, D. T. (1982). Teenage unemployment: Permanent scars or temporary blemishes? In R. B. Freeman and D. A. Wise (Eds.), The Youth Labor Market Problem: Its Nature, Causes, and Consequences, Chapter 10, pp. 349-390. University of Chicago Press.

Eymann, A. and J. Schweri (2015). Horizontal skills mismatch and vocational education. Working paper.

Frei, C. and A. Sousa-Poza (2012). Overqualification: permanent or transitory? Applied Economics 44(14), 1837-1847.

Frühwirth-Schnatter, S., C. Pamminger, A. Weber, and R. Winter-Ebmer (2012). Labor market entry and earnings dynamics: Bayesian inference using mixturesof-experts markov chain clustering. Journal of Applied Econometrics 27(7), 1116-1137.

Genda, Y., A. Kondo, and S. Ohta (2010). Long-term effects of a recession at labor market entry in Japan and the United States. Journal of Human Resources 45(1), 157-196.

Groot, W. and H. Maassen van den Brink (2000). Overeducation in the labor market: a meta-analysis. Economics of Education Review 19(2), 149 - 158.

Hagedorn, M. and I. Manovskii (2013). Job selection over the business cycle. American Economic Review 103(2), 771-803.

Hansen, C. (2007). Asymptotic properties of a robust variance matrix estimator when $\mathrm{T}$ is large. Journal of Econometrics 141, 597-620.

Hershbein, B. (2012). Graduating high school in a recession: Work, education, and home production. The B.E. Journal of Economic Analysis \& Policy 12(1), 1-32. 
Iriondo, I. and T. Pérez-Amal (2013). The effect of educational mismatch on wages using European panel data. Working Paper 700, Queen Mary School of Economics and Finance.

Kahn, L. B. (2010). The long-term labor market consequences of graduating from college in a bad economy. Labour Economics 17, 303-316.

Kahn, L. B. and E. McEntarfer (2014). Employment cyclicality and firm quality. Discussion Paper 8646, IZA.

Kambourov, G. and I. Manovskii (2009). Occupational specificity of human capital. International Economic Review 50, 63-115.

Kondo, A. (2007). Does the first job really matter? State dependency in employment status in Japan. Journal of the Japanese and International Economies 21(3), 379402.

Leuven, E. and H. Oosterbeek (2011). Overeducation and mismatch in the labor market. Discussion Paper 5523, IZA.

Liu, K., K. Salvanes, and E. Sørensen (2016). Good skills in bad times: Cyclical skill mismatch and the long-term effects of graduating in a recession. European Economic Review 84, 3-17.

Mavromaras, K. and S. McGuinness (2012). Overskilling dynamics and education pathways. Economics of Education Review 31(5), 619-628.

McDonald, J. T. and C. Worswick (1999). Wages, implicit contracts, and the business cycle: Evidence from Canadian micro data. Journal of Political Economy 107(4), 884-892.

McGuinness, S. (2006). Overeducation in the labour market. Journal of Economic Surveys 20(3), 387-418.

McGuinness, S., A. Bergin, and A. Whelan (2015). A comparative time series analysis of overeducation in Europe. STYLE Working Paper 5.1, University of Brighton.

McGuinness, S. and P. J. Sloane (2011). Labour market mismatch among UK graduates: An analysis using REFLEX data. Economics of Education Review 30(1), $130-145$.

Moscarini, G. (2001). Excess worker reallocation. Review of Economic Studies 63(3), 593-612. 
Moscarini, G. and F. Vella (2008). Occupational mobility and the business cycle. Working Paper 13819, NBER.

Moulton, B. R. (1986). Random group effects and the precision of regression estimates. Journal of Econometrics 32(3), 385-397.

Mustre-del-Río, J. (2014). Job duration, wages, and the cleansing and sullying effects of recessions. Working Paper 12-08, Federal Reserve Bank of Kansas City.

Neal, D. (1995). Industry-specific human capital: Evidence from displaced workers. Journal of Labor Economics 13(4), 653-677.

OECD (2013). Table: Youth unemployment rate 2012.

Oreopoulos, P., T. von Wachter, and A. Heisz (2012). The short- and long-term career effects of graduating in a recession. American Economic Journal: Applied Economics 4(1), 1-29.

Oyer, P. (2006). Initial labor market conditions and long-term outcomes for economists. Journal of Economic Perspectives 20(3), 143-160.

Raaum, O. and K. Røed (2006). Do business cycle conditions at the time of labor market entry affect future employment prospects. The Review of Economics and Statistics 88(2), 193-210.

Resuchke, D. (2011). Self-employment and geographical mobility in Germany. SOEPPapers No. 417, DIW Berlin.

Robst, J. (1995). Career mobility, job match, and overeducation. Eastern Economic Journal 21(4), 539-550.

Rubb, S. (2003a). Overeducation: a short or long run phenomenon for individuals? Economics of Education Review 22(4), 389-394.

Rubb, S. (2003b). Overeducation in the labor market: a comment and re-analysis of a meta-analysis. Economics of Education Review 22, 621-629.

Rubb, S. (2014). Factors influencing the likelihood of overeducation: a bivariate probit with sample selection framework. Education Economics 22(2), 181-208.

Sohn, K. (2010). The role of cognitive and noncognitive skills in overeducation. Journal of Labor Research 31, 124-145. 
Speer, J. D. (2016). Wages, hours, and the school-to-work transition: the consequences of leaving school in a recession for less-educated men. The BE Journal of Economic Analysis \& Policy 16(1), 97-124.

Stevens, K. (2007). Adult labour market outcomes: the role of economic conditions at entry into the labour market. Mimeo, University College London.

Summerfield, F. (2016). Matching skill and tasks: Cyclical fluctuations in the overqualification of new hires. Working Paper 16-08, Rimini Centre for Economic Analysis.

Tarvid, A. (2015). The role of industry in the prevalence of overeducation in Europe. Procedia Economics and Finance 30, 876-884.

Topel, R. H. and M. P. Ward (1992). Job mobility and the careers of young men. The Quarterly Journal of Economics 107(2), 439-479.

Tsai, Y. (2010). Returns to overeducation: A longitudinal analysis of the U.S. labor market. Economics of Education Review 29, 606-617.

Verdugo, R. R. and N. T. Verdugo (1989). The impact of surplus schooling on earnings. The Journal of Human Resources 24(4), 629-643.

Verhaest, D., S. Sellami, and R. Van der Velden (2015). Differences in horizontal and vertical mismatches across countries and fields of study. International Labour Review.

Verhaest, D. and R. Van der Velden (2013). Cross-country differences in graduate overeducation. European Sociological Review 29(3), 642-653.

Wong, L. Y. (2003). Can the Mortensen-Pissarides model with productivity changes explain US wage inequality? Journal of Labor Economics 21(1), 70-105. 
TABLE 1: Summary statistics

\begin{tabular}{lrcc} 
Variable & Mean & Std. Dev. & $\mathrm{N}$ \\
\hline Male & 0.483 & 0.500 & 13563 \\
Age in Years & 28.476 & 6.166 & 13563 \\
German Citizen & 0.936 & 0.245 & 13563 \\
Married & 0.217 & 0.412 & 13563 \\
& & & \\
Years of Experience & 4.746 & 4.702 & 12222 \\
Years of Education & 13.673 & 2.926 & 13563 \\
Grad: University & 0.367 & 0.482 & 13563 \\
Grad: Tertiary & 0.123 & 0.329 & 13563 \\
Grad: Apprentice & 0.509 & 0.500 & 13563 \\
& & & \\
Working in Occ Trained For & 0.787 & 0.409 & 11819 \\
Actual-Median (OCC) & 0.743 & 2.088 & 12993 \\
Actual-Median (IND) & 1.417 & 2.748 & 13314 \\
Overeducated (OCC) & 0.243 & 0.429 & 12993 \\
Overeducated (IND) & 0.345 & 0.475 & 13314 \\
& & & \\
Baden-Wüerttemberg & 0.135 & 0.342 & 13563 \\
Bavaria & 0.160 & 0.367 & 13563 \\
Berlin & 0.045 & 0.207 & 13563 \\
Brandenburg & 0.031 & 0.175 & 13563 \\
Bremen & 0.007 & 0.084 & 13563 \\
Hamburg & 0.026 & 0.158 & 13563 \\
Hesse & 0.080 & 0.271 & 13563 \\
Mecklenburg-Western Pomerania & 0.019 & 0.137 & 13563 \\
Lower Saxony & 0.089 & 0.285 & 13563 \\
North Rhine-Westphalia & 0.197 & 0.397 & 13563 \\
Rhineland-Palatinate & 0.049 & 0.215 & 13563 \\
Saarland & 0.007 & 0.084 & 13563 \\
Saxony & 0.060 & 0.238 & 13563 \\
Saxony-Anhalt & 0.032 & 0.178 & 13563 \\
Schleswig-Holstein & 0.031 & 0.164 & 13563 \\
Thuringia & 0.044 & 0.174 & 13563 \\
Switch Region & 0.033 & 0.179 & 13563 \\
\hline GOE & & & \\
& & & \\
& & &
\end{tabular}

Source: GSOEP 1994-2012, graduates from university, other tertiary education and apprenticeships. Years of experience for full-time work only. Switch Region refers to workers sampled in a region different from their region of graduation. 
TABLE 2: Education mismatch shares and regional unemployment rates at graduation

\begin{tabular}{ccccc}
$\begin{array}{c}\text { Region } \\
\text { Grad } \\
\text { Urate }\end{array}$ & $\begin{array}{c}\text { Share } \\
\text { Overeducated } \\
\text { OCC }\end{array}$ & $\begin{array}{c}\text { Share } \\
\text { Overeducated } \\
\text { IND }\end{array}$ & $\begin{array}{c}\text { Share in } \\
\text { Occupation } \\
\text { Trained for }\end{array}$ & $\begin{array}{c}\text { Number of } \\
\text { Graduates }\end{array}$ \\
\hline $3.8-5.9$ & 0.179 & 0.269 & 0.774 & 1901 \\
$6.0-7.4$ & 0.197 & 0.295 & 0.787 & 2026 \\
$7.5-8.9$ & 0.270 & 0.375 & 0.768 & 2374 \\
$9.0-10.9$ & 0.283 & 0.404 & 0.834 & 2491 \\
$11.0-14.9$ & 0.299 & 0.420 & 0.803 & 2033 \\
$15.0-20.5$ & 0.205 & 0.265 & 0.746 & 2489
\end{tabular}

Source: GSOEP 1994-2012, graduates from university, other tertiary education and apprenticeships. Mismatch measures defined in the text, Section 3. Weighted using GSOEP enumeration weights. 
TABLE 3: OLS impacts of regional unemployment rates at graduation from highest education obtained on various mismatch measures

\begin{tabular}{|c|c|c|c|c|c|}
\hline & $\begin{array}{c}(1) \\
\text { Pr(OE) } \\
\text { Median } \\
\text { OCC }\end{array}$ & $\begin{array}{l}(2) \\
\operatorname{Pr}(\mathrm{OE}) \\
\text { Median } \\
\text { IND }\end{array}$ & $\begin{array}{l}(3) \\
\text { Distance } \\
\text { Median } \\
\text { OCC }\end{array}$ & $\begin{array}{l}(4) \\
\text { Distance } \\
\text { Median } \\
\text { IND }\end{array}$ & $\begin{array}{l}(5) \\
\text { Pr(Work in } \\
\text { the Occ was } \\
\text { Trained For) }\end{array}$ \\
\hline R. Grad Urate & $\begin{array}{l}0.012 * * \\
(0.004)\end{array}$ & $\begin{array}{l}0.012 * * \\
(0.005)\end{array}$ & $\begin{array}{c}0.032 \\
(0.019)\end{array}$ & $\begin{array}{l}0.073 * * * \\
(0.021)\end{array}$ & $\begin{array}{l}-0.000 \\
(0.004)\end{array}$ \\
\hline University & $\begin{array}{l}-0.008 \\
(0.036)\end{array}$ & $\begin{array}{l}0.321 * * * \\
(0.058)\end{array}$ & $\begin{array}{l}0.558^{* * * *} \\
(0.174)\end{array}$ & $\begin{array}{l}2.536 * * * \\
(0.217)\end{array}$ & $\begin{array}{l}-0.009 \\
(0.028)\end{array}$ \\
\hline Apprentice & $\begin{array}{c}0.004 \\
(0.050)\end{array}$ & $\begin{array}{l}-0.106^{*} \\
(0.055)\end{array}$ & $\begin{array}{c}0.010 \\
(0.181)\end{array}$ & $\begin{array}{l}-0.355 \\
(0.225)\end{array}$ & $\begin{array}{l}-0.149 * * * \\
(0.028)\end{array}$ \\
\hline Age & $\begin{array}{l}0.087 * * * \\
(0.014)\end{array}$ & $\begin{array}{l}0.049 * * \\
(0.022)\end{array}$ & $\begin{array}{l}0.364 * * * \\
(0.105)\end{array}$ & $\begin{array}{l}0.373^{* * *} \\
(0.109)\end{array}$ & $\begin{array}{l}-0.032 \\
(0.024)\end{array}$ \\
\hline $\mathrm{Age}^{2}$ & $\begin{array}{l}-0.001 * * * \\
(0.000)\end{array}$ & $\begin{array}{l}-0.000 \\
(0.000)\end{array}$ & $\begin{array}{l}-0.004 * \\
(0.002)\end{array}$ & $\begin{array}{l}-0.004^{*} \\
(0.002)\end{array}$ & $\begin{array}{l}0.000 \\
(0.000)\end{array}$ \\
\hline Experience & $\begin{array}{l}-0.027 * * * \\
(0.006)\end{array}$ & $\begin{array}{l}-0.011 \\
(0.008)\end{array}$ & $\begin{array}{l}-0.143 * * * \\
(0.034)\end{array}$ & $\begin{array}{l}-0.093 * * \\
(0.038)\end{array}$ & $\begin{array}{l}0.015^{*} \\
(0.007)\end{array}$ \\
\hline Experience $^{2}$ & $\begin{array}{c}0.001 * \\
(0.000)\end{array}$ & $\begin{array}{l}-0.000 \\
(0.000)\end{array}$ & $\begin{array}{c}0.002 \\
(0.002)\end{array}$ & $\begin{array}{l}-0.000 \\
(0.002)\end{array}$ & $\begin{array}{l}-0.001 * * \\
(0.000)\end{array}$ \\
\hline Married & $\begin{array}{l}-0.020 \\
(0.021)\end{array}$ & $\begin{array}{l}-0.024 \\
(0.021)\end{array}$ & $\begin{array}{l}-0.281 * * \\
(0.111)\end{array}$ & $\begin{array}{l}-0.226 \\
(0.137)\end{array}$ & $\begin{array}{l}-0.031 \\
(0.033)\end{array}$ \\
\hline Male & $\begin{array}{l}-0.018 \\
(0.024)\end{array}$ & $\begin{array}{l}0.048 \\
(0.046)\end{array}$ & $\begin{array}{l}0.019 \\
(0.108)\end{array}$ & $\begin{array}{c}0.203 \\
(0.119)\end{array}$ & $\begin{array}{l}-0.037 * \\
(0.019)\end{array}$ \\
\hline German & $\begin{array}{c}0.070 \\
(0.050)\end{array}$ & $\begin{array}{c}0.036 \\
(0.038)\end{array}$ & $\begin{array}{l}0.128 \\
(0.266)\end{array}$ & $\begin{array}{c}0.208 \\
(0.297)\end{array}$ & $\begin{array}{l}0.089 * * * \\
(0.025)\end{array}$ \\
\hline Region Switch & $\begin{array}{c}0.070 \\
(0.046)\end{array}$ & $\begin{array}{l}0.043^{*} \\
(0.020)\end{array}$ & $\begin{array}{l}0.330^{*} \\
(0.158)\end{array}$ & $\begin{array}{l}0.287 * * * \\
(0.087)\end{array}$ & $\begin{array}{l}0.020 \\
(0.031)\end{array}$ \\
\hline Constant & $\begin{array}{l}-1.556^{* * * *} \\
(0.225)\end{array}$ & $\begin{array}{l}-1.018 * * \\
(0.374)\end{array}$ & $\begin{array}{l}-6.807 * * * \\
(1.400)\end{array}$ & $\begin{array}{l}-7.727 * * * \\
(1.705)\end{array}$ & $\begin{array}{l}1.237 * * * \\
(0.357)\end{array}$ \\
\hline WBoot p-values & & & & & \\
\hline R. Grad Urate & 0.058 & 0.108 & 0.177 & 0.062 & 0.887 \\
\hline $\mathrm{N}$ & 11,892 & 12,215 & 11,892 & 12,215 & 12,191 \\
\hline $\mathrm{R}^{2}$ & 0.088 & 0.361 & 0.148 & 0.477 & 0.055 \\
\hline
\end{tabular}

Source: GSOEP 1994-2012. Regional unemployment rates exclude self-employed and pool the effects of graduation timing across all individuals using their highest achieved education level. Education levels: UNI-university and APR-Apprenticeship. Omitted education dummy is TERT-technical schooling, such as medical or teaching or other vocational schooling. Estimates include dummies for region of graduation. Region Switch is a dummy to indicate those who reside in different region relative to graduation date. Standard errors in parentheses clustered on region of graduation. Estimates weighted with enumeration weights. Wild cluster bootstrap p-values at the region level impose the null hypothesis on the variable of interest $(\hat{\gamma}=0)$ using 999 repetitions. ${ }^{* * *}$ $\mathrm{p}<0.01,{ }^{* *} \mathrm{p}<0.05,{ }^{*} \mathrm{p}<0.1$ for all coefficients and test statistics. 
TABLE 4: IV impacts of regional unemployment rates at graduation from highest education obtained on various mismatch measures

\begin{tabular}{|c|c|c|c|c|c|}
\hline Second Stage & $\begin{array}{l}(1) \\
\text { Pr(OE) } \\
\text { Median } \\
\text { OCC }\end{array}$ & $\begin{array}{l}(2) \\
\operatorname{Pr}(\mathrm{OE}) \\
\text { Median } \\
\text { IND }\end{array}$ & $\begin{array}{l}(3) \\
\text { Distance } \\
\text { Median } \\
\text { OCC }\end{array}$ & $\begin{array}{l}(4) \\
\text { Distance } \\
\text { Median } \\
\text { IND }\end{array}$ & $\begin{array}{l}(5) \\
\text { Pr(Work in } \\
\text { the Occ was } \\
\text { Trained For) }\end{array}$ \\
\hline R. Grad Urate & $\begin{array}{l}0.014 * * * \\
(0.005)\end{array}$ & $\begin{array}{l}0.010 * * \\
(0.005)\end{array}$ & $\begin{array}{c}0.045 * * \\
(0.023)\end{array}$ & $\begin{array}{l}0.068^{* * *} \\
(0.019)\end{array}$ & $\begin{array}{l}-0.003 \\
(0.004)\end{array}$ \\
\hline University & $\begin{array}{c}0.032 \\
(0.034)\end{array}$ & $\begin{array}{l}0.334 * * * \\
(0.049)\end{array}$ & $\begin{array}{l}0.771 \text { *** } \\
(0.152)\end{array}$ & $\begin{array}{l}2.673 * * * \\
(0.175)\end{array}$ & $\begin{array}{l}-0.033 \\
(0.027)\end{array}$ \\
\hline Apprentice & $\begin{array}{l}-0.023 \\
(0.058)\end{array}$ & $\begin{array}{l}-0.121 * * \\
(0.053)\end{array}$ & $\begin{array}{l}-0.089 \\
(0.196)\end{array}$ & $\begin{array}{l}-0.410 * \\
(0.216)\end{array}$ & $\begin{array}{l}-0.152 * * * \\
(0.027)\end{array}$ \\
\hline Age & $\begin{array}{l}0.071 * * * \\
(0.010)\end{array}$ & $\begin{array}{l}0.062 * * * \\
(0.015)\end{array}$ & $\begin{array}{l}0.396^{* * * *} \\
(0.053)\end{array}$ & $\begin{array}{l}0.494 * * * \\
(0.065)\end{array}$ & $\begin{array}{l}-0.002 \\
(0.012)\end{array}$ \\
\hline $\mathrm{Age}^{2}$ & $\begin{array}{l}-0.001 * * * \\
(0.000)\end{array}$ & $\begin{array}{l}-0.001 * * * \\
(0.000)\end{array}$ & $\begin{array}{l}-0.005^{* * * *} \\
(0.001)\end{array}$ & $\begin{array}{l}-0.007 * * * \\
(0.001)\end{array}$ & $\begin{array}{l}-0.000 \\
(0.000)\end{array}$ \\
\hline Married & $\begin{array}{c}-0.035^{*} \\
(0.020)\end{array}$ & $\begin{array}{l}-0.035^{*} \\
(0.021)\end{array}$ & $\begin{array}{l}-0.375^{* * * *} \\
(0.101)\end{array}$ & $\begin{array}{l}-0.291 * * \\
(0.119)\end{array}$ & $\begin{array}{l}-0.025 \\
(0.032)\end{array}$ \\
\hline Male & $\begin{array}{l}-0.020 \\
(0.020)\end{array}$ & $\begin{array}{c}0.036 \\
(0.038)\end{array}$ & $\begin{array}{l}-0.007 \\
(0.086)\end{array}$ & $\begin{array}{l}0.140 \\
(0.109)\end{array}$ & $\begin{array}{l}-0.031 \\
(0.021)\end{array}$ \\
\hline German & $\begin{array}{c}0.065 \\
(0.048)\end{array}$ & $\begin{array}{l}0.028 \\
(0.037)\end{array}$ & $\begin{array}{c}0.070 \\
(0.241)\end{array}$ & $\begin{array}{c}0.119 \\
(0.270)\end{array}$ & $\begin{array}{l}0.090^{* * * *} \\
(0.029)\end{array}$ \\
\hline Region Switch & $\begin{array}{l}0.089 * * \\
(0.040)\end{array}$ & $\begin{array}{l}0.047 * * * \\
(0.016)\end{array}$ & $\begin{array}{l}0.427 * * * \\
(0.159)\end{array}$ & $\begin{array}{l}0.362 * * * \\
(0.069)\end{array}$ & $\begin{array}{c}0.030 \\
(0.030)\end{array}$ \\
\hline \multicolumn{6}{|l|}{ First Stage: R. Grad Urate } \\
\hline R14. Mod Urate (UNI) & $\begin{array}{l}0.892 * * * \\
(0.017)\end{array}$ & $\begin{array}{l}0.894 * * * \\
(0.019)\end{array}$ & $\begin{array}{l}0.892 * * * \\
(0.017)\end{array}$ & $\begin{array}{l}0.894 * * * \\
(0.019)\end{array}$ & $\begin{array}{l}0.891 * * * \\
(0.019)\end{array}$ \\
\hline R14. Mod Urate (TERT) & $\begin{array}{l}0.874 * * * \\
(0.039)\end{array}$ & $\begin{array}{l}0.876^{* * * *} \\
(0.040)\end{array}$ & $\begin{array}{l}0.874 * * * \\
(0.039)\end{array}$ & $\begin{array}{l}0.876^{* * * *} \\
(0.040)\end{array}$ & $\begin{array}{l}0.871 * * * \\
(0.041)\end{array}$ \\
\hline R14. Mod Urate (APR) & $\begin{array}{l}0.923 * * * \\
(0.012)\end{array}$ & $\begin{array}{l}0.923 * * * \\
(0.013)\end{array}$ & $\begin{array}{l}0.923^{* * *} \\
(0.012)\end{array}$ & $\begin{array}{l}0.923 * * * \\
(0.013)\end{array}$ & $\begin{array}{l}0.922 * * * \\
(0.013)\end{array}$ \\
\hline Multivariate $F(\mathrm{AP})$ & $2120.39^{* * *}$ & $1909.44 * * *$ & $2120.39 * * *$ & $1909.44 * * *$ & $1836.86 * * *$ \\
\hline Sargan-Hansen $\chi^{2}$ & 1.210 & 4.095 & 0.906 & 1.155 & 3.224 \\
\hline $\mathrm{N}$ & 12,993 & 13,314 & 12,993 & 13,314 & 12,529 \\
\hline $\mathrm{R}^{2}$ & 0.063 & 0.328 & 0.132 & 0.454 & 0.029 \\
\hline
\end{tabular}

Source: GSOEP 1994-2012. Regional unemployment rates exclude self-employed and pool labour market entry effects across all individuals using their highest achieved education level. Education levels: UNI-university and APR-Apprenticeship. Omitted education dummy is TERT-technical schooling, such as medical or teaching or other vocational schooling. Estimates include dummies for region of graduation. Region Switch is a dummy to indicate those who reside in different region relative to graduation date. Standard errors in parentheses clustered on region of graduation. Estimates weighted with enumeration weights. Reg. Grad Urate is instrumented with R14 Mod Urate (UNI $\mid$ TERT $\mid$ APR), the unemployment rates specific to each of the three education levels in the region where an individual resided at age 14 at the modal graduation year for their age cohort following Kahn (2010). $\chi^{2}$ is the test statistic from the Hansen $\mathrm{J}$ test for overidentification of all instruments with a null-hypothesis that instruments are exogenous. $F(\mathrm{AP})$ is the multivariate $\mathrm{F}$-test for joint significance of instruments from Angrist and Pischke (2009). ${ }^{* * *} \mathrm{p}<0.01,{ }^{* *} \mathrm{p}<0.05,{ }^{*} \mathrm{p}<0.1$ for all coefficients and test statistics. 
TABLE 5: IV impacts of regional unemployment rates at graduation from specific level of education obtained on various mismatch measures

\begin{tabular}{|c|c|c|c|c|c|}
\hline \multirow[b]{4}{*}{ Second Stage } & (1) & (2) & (3) & (4) & (5) \\
\hline & $\operatorname{Pr}(\mathrm{OE})$ & $\operatorname{Pr}(\mathrm{OE})$ & Distance & Distance & $\operatorname{Pr}$ (Work in \\
\hline & Median & Median & Median & Median & the Occ was \\
\hline & $\mathrm{OCC}$ & IND & $\mathrm{OCC}$ & IND & Trained For) \\
\hline \multirow[t]{2}{*}{ R. Grad Urate (UNI) } & $0.016 * * *$ & $0.017 * * *$ & 0.035 & $0.091 * * *$ & 0.001 \\
\hline & $(0.006)$ & $(0.005)$ & $(0.027)$ & $(0.026)$ & $(0.005)$ \\
\hline \multirow[t]{2}{*}{ R. Grad Urate (TERT) } & 0.009 & 0.006 & $0.034 *$ & $0.058 *$ & 0.003 \\
\hline & $(0.006)$ & $(0.009)$ & $(0.020)$ & $(0.034)$ & $(0.006)$ \\
\hline \multirow[t]{2}{*}{ R. Grad Urate (APR) } & $0.013 * *$ & 0.005 & $0.050 * *$ & $0.050 * *$ & $-0.008 *$ \\
\hline & $(0.005)$ & $(0.005)$ & $(0.023)$ & $(0.021)$ & $(0.004)$ \\
\hline \multirow[t]{2}{*}{ University } & -0.039 & $0.215^{*}$ & $0.746 * *$ & $2.351 * * *$ & -0.019 \\
\hline & $(0.074)$ & $(0.116)$ & $(0.336)$ & $(0.411)$ & $(0.076)$ \\
\hline \multirow[t]{2}{*}{ Apprentice } & -0.063 & -0.124 & -0.249 & -0.331 & -0.050 \\
\hline & $(0.103)$ & $(0.140)$ & $(0.363)$ & $(0.448)$ & $(0.069)$ \\
\hline \multirow[t]{2}{*}{ Age } & $0.071 * * *$ & $0.061 * * *$ & $0.397 * * *$ & $0.491 * * *$ & -0.002 \\
\hline & $(0.010)$ & $(0.014)$ & $(0.053)$ & $(0.063)$ & $(0.011)$ \\
\hline \multirow[t]{2}{*}{$\mathrm{Age}^{2}$} & $-0.001 * * *$ & $-0.001 * * *$ & $-0.005 * * *$ & $-0.006 * * *$ & -0.000 \\
\hline & $(0.000)$ & $(0.000)$ & $(0.001)$ & $(0.001)$ & $(0.000)$ \\
\hline \multirow[t]{2}{*}{ Married } & $-0.035^{*}$ & $-0.036 *$ & $-0.375^{* * *}$ & $-0.294 * *$ & -0.026 \\
\hline & $(0.020)$ & $(0.021)$ & $(0.101)$ & $(0.119)$ & $(0.032)$ \\
\hline \multirow[t]{2}{*}{ Male } & -0.020 & 0.038 & -0.010 & 0.146 & -0.029 \\
\hline & $(0.019)$ & $(0.037)$ & $(0.088)$ & $(0.108)$ & $(0.021)$ \\
\hline \multirow[t]{2}{*}{ German } & 0.067 & 0.033 & 0.068 & 0.135 & $0.092 * * *$ \\
\hline & $(0.048)$ & $(0.038)$ & $(0.241)$ & $(0.276)$ & $(0.028)$ \\
\hline \multirow[t]{2}{*}{ Region Switch } & $0.090 * *$ & $0.048 * * *$ & $0.427 * * *$ & $0.365^{* * *}$ & 0.032 \\
\hline & $(0.040)$ & $(0.016)$ & $(0.158)$ & $(0.067)$ & $(0.030)$ \\
\hline \multicolumn{6}{|l|}{ First Stage: R. Grad Urate (UNI) } \\
\hline \multirow[t]{2}{*}{ R. Mod Urate 14 (UNI) } & $0.927 * * *$ & $0.928 * * *$ & $0.927 * * *$ & $0.928 * * *$ & $0.932 * * *$ \\
\hline & $(0.012)$ & $(0.013)$ & $(0.012)$ & $(0.013)$ & $(0.012)$ \\
\hline Multivariate $F$ (AP) & $5900.11 * * *$ & $4976.10 * * *$ & $5900.11 * * *$ & $4976.10 * * *$ & $5939.14 * * *$ \\
\hline \multicolumn{6}{|l|}{ First Stage: R. Grad Urate (TERT) } \\
\hline \multirow[t]{2}{*}{ R. Mod Urate 14 (TERT) } & $0.968 * * *$ & $0.969 * * *$ & $0.968 * * *$ & $0.969 * * *$ & $0.969 * * *$ \\
\hline & $(0.007)$ & $(0.006)$ & $(0.007)$ & $(0.006)$ & $(0.006)$ \\
\hline Multivariate $F$ (AP) & $20830.4 * * *$ & $23402.6 * * *$ & $20830.4 * * *$ & $23402.6 * * *$ & $24723.4 * * *$ \\
\hline \multicolumn{6}{|l|}{ First Stage: R. Grad Urate (APR) } \\
\hline \multirow[t]{2}{*}{ R. Mod Urate 14 (APR) } & $0.964 * * *$ & $0.963 * * *$ & $0.964 * * *$ & $0.963 * * *$ & $0.960 * * *$ \\
\hline & $(0.003)$ & $(0.004)$ & $(0.003)$ & $(0.004)$ & $(0.005)$ \\
\hline Multivariate $F$ (AP) & $99690.5 * * *$ & $50508.7 * * *$ & $99690.5 * * *$ & $50508.7 * * *$ & $34361.0 * * *$ \\
\hline $\mathrm{N}$ & 12,993 & 13,314 & 12,993 & 13,314 & 12,529 \\
\hline $\mathrm{R}^{2}$ & 0.063 & 0.329 & 0.133 & 0.454 & 0.030 \\
\hline
\end{tabular}

Source: GSOEP 1994-2012. Regional unemployment rates exclude self-employed and are specific to an individual's highest achieved education level. Education levels: UNI-university and APR-Apprenticeship and TERT-technical schooling (omitted group), such as medical or teaching or other vocational schooling. Estimates include dummies for region of graduation. Region Switch is a dummy to indicate those who reside in different region relative to graduation date. Standard errors in parentheses clustered on region of graduation. Estimates weighted with enumeration weights. Reg. Grad Urate variables are instrumented with R14 Mod Urate (UNI | TERT | APR) variables, the unemployment rates specific to each of the three education levels in the region where an individual resided at age 14 at the modal graduation year for their age cohort following Kahn (2010). Model is just-identified. Multivariate $F$ (AP) is the F-test for joint significance of instruments from Angrist and Pischke (2009). ${ }^{* * *} \mathrm{p}<0.01,{ }^{* *} \mathrm{p}<0.05,{ }^{*} \mathrm{p}<0.1$ for all coefficients and test statistics. 
TABLE 6: The marginal effect of labour market entry conditions on overeducation by grouped years since graduation

\begin{tabular}{|c|c|c|c|c|c|}
\hline $\begin{array}{c}\text { Years } \\
\text { Since } \\
\text { Graduation }\end{array}$ & $\begin{array}{l}(1) \\
\text { Pr(OE) } \\
\text { Median } \\
\text { OCC }\end{array}$ & $\begin{array}{l}(2) \\
\text { Pr(OE) } \\
\text { Median } \\
\text { IND }\end{array}$ & $\begin{array}{l}\quad(3) \\
\text { Distance } \\
\text { Median } \\
\text { OCC } \\
\end{array}$ & $\begin{array}{l}\quad(4) \\
\text { Distance } \\
\text { Median } \\
\text { IND } \\
\end{array}$ & $\begin{array}{l}(5) \\
\text { Pr(Work in } \\
\text { the OCC was } \\
\text { Trained For) }\end{array}$ \\
\hline \multicolumn{6}{|c|}{ All Schooling Types } \\
\hline 0 & $\begin{array}{l}0.010^{* *} \\
(0.004)\end{array}$ & $\begin{array}{c}0.003 \\
(0.006)\end{array}$ & $\begin{array}{c}0.012 \\
(0.021)\end{array}$ & $\begin{array}{c}0.020 \\
(0.021)\end{array}$ & $\begin{array}{l}-0.018^{*} \\
(0.009)\end{array}$ \\
\hline $1-3$ & $\begin{array}{l}0.009 * * \\
(0.004)\end{array}$ & $\begin{array}{l}0.011 * * \\
(0.004)\end{array}$ & $\begin{array}{c}0.022 \\
(0.021)\end{array}$ & $\begin{array}{l}0.071 * * * \\
(0.020)\end{array}$ & $\begin{array}{l}-0.004 \\
(0.005)\end{array}$ \\
\hline $4-6$ & $\begin{array}{l}0.014 * * \\
(0.005)\end{array}$ & $\begin{array}{l}0.012 * * \\
(0.005)\end{array}$ & $\begin{array}{c}0.035 \\
(0.023)\end{array}$ & $\begin{array}{l}0.071 * * * \\
(0.019)\end{array}$ & $\begin{array}{c}0.001 \\
(0.004)\end{array}$ \\
\hline $5-9$ & $\begin{array}{c}0.014 * \\
(0.008)\end{array}$ & $\begin{array}{c}0.007 \\
(0.006)\end{array}$ & $\begin{array}{c}0.054^{*} \\
(0.027)\end{array}$ & $\begin{array}{l}0.075 * * \\
(0.029)\end{array}$ & $\begin{array}{l}-0.002 \\
(0.005)\end{array}$ \\
\hline $10-12$ & $\begin{array}{c}0.012 \\
(0.008)\end{array}$ & $\begin{array}{c}0.010 \\
(0.008)\end{array}$ & $\begin{array}{c}0.063 \\
(0.039)\end{array}$ & $\begin{array}{c}0.063^{*} \\
(0.035)\end{array}$ & $\begin{array}{l}-0.003 \\
(0.006)\end{array}$ \\
\hline $13-15$ & $\begin{array}{c}0.004 \\
(0.009)\end{array}$ & $\begin{array}{c}0.011 \\
(0.008)\end{array}$ & $\begin{array}{c}0.051 \\
(0.048)\end{array}$ & $\begin{array}{c}0.031 \\
(0.058)\end{array}$ & $\begin{array}{r}0.0004 \\
(0.010)\end{array}$ \\
\hline $16-18$ & $\begin{array}{c}0.024 \\
(0.016)\end{array}$ & $\begin{array}{c}0.008 \\
(0.010)\end{array}$ & $\begin{array}{c}0.119 \\
(0.091)\end{array}$ & $\begin{array}{c}0.063 \\
(0.067)\end{array}$ & $\begin{array}{l}-0.012 \\
(0.021)\end{array}$ \\
\hline \multicolumn{6}{|c|}{ University Only } \\
\hline 0 & $\begin{array}{c}0.006 \\
(0.006)\end{array}$ & $\begin{array}{l}-0.017 * * \\
(0.006)\end{array}$ & $\begin{array}{l}-0.020 \\
(0.025)\end{array}$ & $\begin{array}{l}-0.064 * \\
(0.033)\end{array}$ & $\begin{array}{l}-0.025^{* * *} \\
(0.006)\end{array}$ \\
\hline $1-3$ & $\begin{array}{c}0.002 \\
(0.004)\end{array}$ & $\begin{array}{r}0.007 * \\
(0.004)\end{array}$ & $\begin{array}{l}-0.022 \\
(0.016)\end{array}$ & $\begin{array}{c}0.033 \\
(0.028)\end{array}$ & $\begin{array}{l}-0.001 \\
(0.006)\end{array}$ \\
\hline $4-6$ & $\begin{array}{c}0.010 \\
(0.006)\end{array}$ & $\begin{array}{l}0.020 * * * \\
(0.003)\end{array}$ & $\begin{array}{l}0.008 \\
(0.026)\end{array}$ & $\begin{array}{c}0.076^{* *} \\
(0.026)\end{array}$ & $\begin{array}{l}0.009 \\
(0.005)\end{array}$ \\
\hline $5-9$ & $\begin{array}{c}0.016^{*} \\
(0.009)\end{array}$ & $\begin{array}{l}0.027 * * * \\
(0.005)\end{array}$ & $\begin{array}{c}0.044 \\
(0.040)\end{array}$ & $\begin{array}{l}0.118 * * * \\
(0.032)\end{array}$ & $\begin{array}{c}0.012 * \\
(0.006)\end{array}$ \\
\hline $10-12$ & $\begin{array}{c}0.018^{*} \\
(0.010)\end{array}$ & $\begin{array}{l}0.025^{* * *} \\
(0.007)\end{array}$ & $\begin{array}{c}0.050 \\
(0.045)\end{array}$ & $\begin{array}{l}0.105^{* *} \\
(0.045)\end{array}$ & $\begin{array}{l}0.014 * * \\
(0.006)\end{array}$ \\
\hline $13-15$ & $\begin{array}{c}0.033^{*} \\
(0.015)\end{array}$ & $\begin{array}{l}0.032 * * \\
(0.012)\end{array}$ & $\begin{array}{c}0.121 * \\
(0.063)\end{array}$ & $\begin{array}{l}0.194 * * \\
(0.070)\end{array}$ & $\begin{array}{c}0.009 \\
(0.014)\end{array}$ \\
\hline $16-18$ & $\begin{array}{c}0.030 \\
(0.022)\end{array}$ & $\begin{array}{r}0.034^{*} \\
(0.019)\end{array}$ & $\begin{array}{c}0.147 \\
(0.123)\end{array}$ & $\begin{array}{c}0.271 * \\
(0.132)\end{array}$ & $\begin{array}{l}-0.011 \\
(0.030)\end{array}$ \\
\hline $\mathrm{N}$ & 13386 & 13710 & 13386 & 13710 & 12733 \\
\hline
\end{tabular}

Source: GSOEP 1994-2012. Marginal effects from OLS regressions including dummies for grouped years since graduation, the regional unemployment rate at graduation and their interactions. All Schooling types from regressions with pooled unemployment rates from all post-secondary graduates. University only marginal effects calculated for university graduates from regressions with unemployment rates split by education type. Regional unemployment rates exclude self-employed. Other control variables include education levels: UNI-university, TERT-technical schooling such as medical or teaching or other vocational schooling, APR-Apprenticeship, dummies for region of graduation, year dummies, dummies for German nationality, gender and marital status, and age in years and its quadratic. Standard errors in parentheses clustered on region of graduation. Estimates weighted with enumeration weights. 
FIGURE 1: Entry conditions and the probability of overeducation within 4-digit occupations

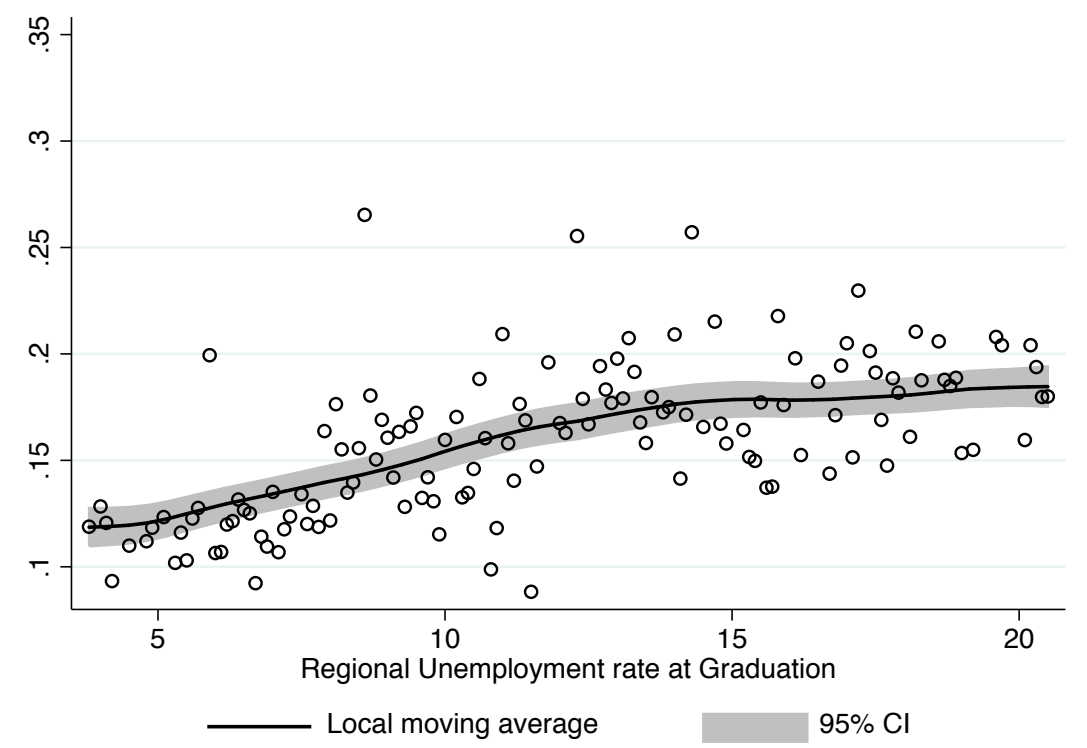

Source: GSOEP 1994-2012. Local moving average of the probability of overeducation using the occupation-median based measure. Calculated with Epanechnikov kernel using a bandwidth of 1.63 and a pilot bandwidth of 2.45.

FIGURE 2: Entry conditions and the probability of overeducation within 2-digit industries

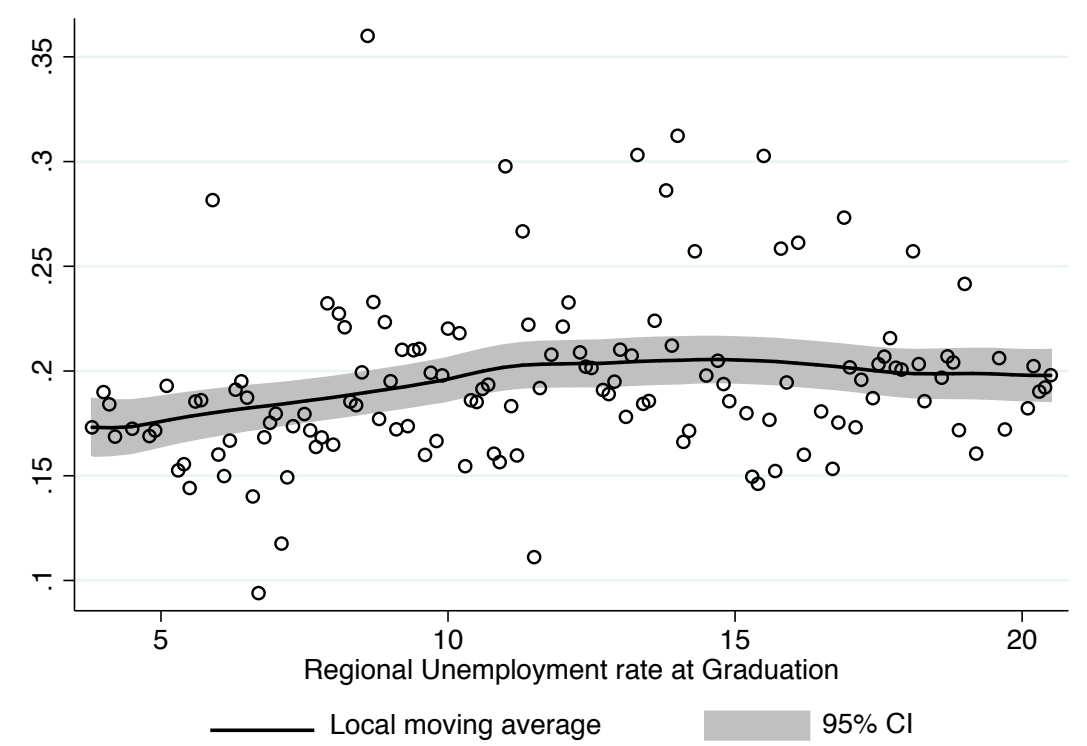

Source: GSOEP 1994-2012. Local moving average of the probability of overeducation using the industry-median based measure. Calculated with Epanechnikov kernel using a bandwidth of 1.81 and a pilot bandwidth of 2.72 . 


\section{Appendix}

TABLE A1: Mismatch Measure Correlation Matrix

\begin{tabular}{lccccc} 
& $\begin{array}{c}\operatorname{Pr}(\mathrm{OE}) \\
\text { OCC }\end{array}$ & $\begin{array}{c}\operatorname{Pr}(\mathrm{OE}) \\
\text { IND }\end{array}$ & $\begin{array}{c}\text { Distance } \\
\text { OCC }\end{array}$ & $\begin{array}{c}\text { Distance } \\
\text { IND }\end{array}$ & $\begin{array}{c}\text { Occ } \\
\text { Trained for }\end{array}$ \\
\hline $\operatorname{Pr}(\mathrm{OE})$ OCC & 1 & & & & \\
$\operatorname{Pr}(\mathrm{OE})$ IND & 0.48 & 1 & & & \\
Distance OCC & 0.76 & 0.53 & 1 & & \\
Distance IND & 0.46 & 0.82 & 0.62 & 1 & \\
Occ Trained for & -0.03 & 0.07 & -0.04 & 0.09 & 1 \\
\hline
\end{tabular}

Overeducation and distance measures are vertical measures of mismatch based on years of schooling. Works in Occupation Trained For is a horizontal measure of mismatch based on occupation-specific skill.

TABLE A2: T-test for difference in the probability of overeduation within occupation, by number of observations within cells

\begin{tabular}{lccc} 
& $\begin{array}{c}\text { Excluding } \\
\mathrm{N}_{4 D}<10\end{array}$ & $\begin{array}{c}\text { Including } \\
\mathrm{N}_{3 D} \geq 10\end{array}$ & Difference \\
\hline Mean & 0.2237 & 0.2250 & 0.0013 \\
SE & $(0.0036)$ & $(0.0035)$ & $(0.0050)$ \\
$\mathrm{N}$ & 13386 & 13945 & \\
\hline
\end{tabular}

Two-sample t-test for equality of means, occupational overeducation measure.

Original sample (left column) excluding observations in 4-digit occupation-year groups with $N<10$. Larger sample (centre column) includes dropped observations that are recovered when rounding to the 3-digit level and evaluating median education at the 3-digit level. 
TABLE A3: Robustness check: IV impacts on overeducation measures, comparing actual to mean education

\begin{tabular}{|c|c|c|c|c|}
\hline Second Stage & $\begin{array}{l}(1) \\
\text { Pr(OE) } \\
\text { Mean } \\
\text { OCC }\end{array}$ & \begin{tabular}{l}
\multicolumn{1}{c}{$(2)$} \\
$\operatorname{Pr}(\mathrm{OE})$ \\
Mean \\
IND
\end{tabular} & \begin{tabular}{l}
\multicolumn{1}{c}{$(3)$} \\
Distance \\
Mean \\
OCC
\end{tabular} & \begin{tabular}{l}
\multicolumn{1}{c}{$(4)$} \\
Distance \\
Mean \\
IND
\end{tabular} \\
\hline R. Grad Urate (UNI) & $\begin{array}{l}0.012 * \\
(0.007)\end{array}$ & $\begin{array}{l}0.023 * * * \\
(0.004)\end{array}$ & $\begin{array}{l}0.029 \\
(0.029)\end{array}$ & $\begin{array}{l}0.070 * * * \\
(0.018)\end{array}$ \\
\hline R. Grad Urate (TERT) & $\begin{array}{l}0.008 \\
(0.006)\end{array}$ & $\begin{array}{l}0.007 \\
(0.007)\end{array}$ & $\begin{array}{l}0.039 * \\
(0.021)\end{array}$ & $\begin{array}{l}0.036 \\
(0.033)\end{array}$ \\
\hline R. Grad Urate (APR) & $\begin{array}{l}0.010 \\
(0.006)\end{array}$ & $\begin{array}{l}0.007 \\
(0.005)\end{array}$ & $\begin{array}{l}0.052 * * \\
(0.023)\end{array}$ & $\begin{array}{l}0.048 * * \\
(0.024)\end{array}$ \\
\hline University & $\begin{array}{l}0.078 \\
(0.057)\end{array}$ & $\begin{array}{l}0.265^{* * *} * \\
(0.079)\end{array}$ & $\begin{array}{l}1.275^{* * * *} \\
(0.333)\end{array}$ & $\begin{array}{l}2.474 * * * \\
(0.432)\end{array}$ \\
\hline Apprentice & $\begin{array}{l}-0.053 \\
(0.081)\end{array}$ & $\begin{array}{l}-0.058 \\
(0.087)\end{array}$ & $\begin{array}{l}-0.329 \\
(0.330)\end{array}$ & $\begin{array}{l}-0.581 \\
(0.448)\end{array}$ \\
\hline Age & $\begin{array}{l}0.059 * * * \\
(0.009)\end{array}$ & $\begin{array}{l}0.048^{* * * *} \\
(0.013)\end{array}$ & $\begin{array}{l}0.385 * * * \\
(0.048)\end{array}$ & $\begin{array}{l}0.483 * * * \\
(0.064)\end{array}$ \\
\hline $\mathrm{Age}^{2}$ & $\begin{array}{l}-0.001 * * * \\
(0.000)\end{array}$ & $\begin{array}{l}-0.001 * * * \\
(0.000)\end{array}$ & $\begin{array}{l}-0.005^{* * *} \\
(0.001)\end{array}$ & $\begin{array}{l}-0.006 * * * \\
(0.001)\end{array}$ \\
\hline Married & $\begin{array}{l}-0.047 * * \\
(0.020)\end{array}$ & $\begin{array}{l}-0.018 \\
(0.016)\end{array}$ & $\begin{array}{l}-0.330^{* * * *} \\
(0.086)\end{array}$ & $\begin{array}{l}-0.287 * * * \\
(0.094)\end{array}$ \\
\hline Male & $\begin{array}{l}0.014 \\
(0.020)\end{array}$ & $\begin{array}{l}0.039 \\
(0.026)\end{array}$ & $\begin{array}{l}-0.022 \\
(0.075)\end{array}$ & $\begin{array}{l}0.026 \\
(0.062)\end{array}$ \\
\hline German & $\begin{array}{l}0.061 \\
(0.049)\end{array}$ & $\begin{array}{l}0.001 \\
(0.036)\end{array}$ & $\begin{array}{l}0.032 \\
(0.223)\end{array}$ & $\begin{array}{l}0.118 \\
(0.268)\end{array}$ \\
\hline Region Switch & $\begin{array}{l}0.104 * * * \\
(0.035)\end{array}$ & $\begin{array}{l}0.032 \\
(0.034)\end{array}$ & $\begin{array}{l}0.398 * * * \\
(0.148)\end{array}$ & $\begin{array}{l}0.398 * * * \\
(0.094)\end{array}$ \\
\hline \multicolumn{5}{|l|}{ First Stage - UNI } \\
\hline R. Grad Urate 14 (UNI) & $\begin{array}{l}0.927 * * * \\
(0.012)\end{array}$ & $\begin{array}{l}0.928^{* * * *} \\
(0.013)\end{array}$ & $\begin{array}{l}0.927 * * * \\
(0.012)\end{array}$ & $\begin{array}{l}0.928 * * * \\
(0.013)\end{array}$ \\
\hline Multivariate $F$ (AP) & $5900.11 * * *$ & $4976.10^{* * *}$ & $5900.11 * * *$ & $4976.10^{* * *}$ \\
\hline \multicolumn{5}{|l|}{ First Stage - TERT } \\
\hline R. Grad Urate 14 (TERT) & $\begin{array}{l}0.968 * * * \\
(0.007)\end{array}$ & $\begin{array}{l}0.969 * * * \\
(0.006)\end{array}$ & $\begin{array}{l}0.968 * * * \\
(0.007)\end{array}$ & $\begin{array}{l}0.969 * * * \\
(0.006)\end{array}$ \\
\hline Multivariate $F$ (AP) & $20830.4 * * *$ & $23402.6 * * *$ & $20830.4 * * *$ & $23402.6^{* * *}$ \\
\hline \multicolumn{5}{|l|}{ First Stage - APR } \\
\hline R. Grad Urate 14 (APR) & $\begin{array}{l}0.964 * * * \\
(0.003)\end{array}$ & $\begin{array}{l}0.963 * * * \\
(0.004)\end{array}$ & $\begin{array}{l}0.964 * * * \\
(0.003)\end{array}$ & $\begin{array}{l}0.963 * * * \\
(0.004)\end{array}$ \\
\hline Multivariate $F$ (AP) & $99690.5^{* * *}$ & $50508.7 * * *$ & $99690.5 * * *$ & $50508.7 * * *$ \\
\hline $\mathrm{N}$ & 12,993 & 13,314 & 12,993 & 13,314 \\
\hline $\mathrm{R}^{2}$ & 0.098 & 0.350 & 0.234 & 0.546 \\
\hline
\end{tabular}

Source: GSOEP 1994-2012. Regional unemployment rates exclude self-employed and pool the effects of graduation timing across all individuals using their highest achieved education level. Education levels: UNI-university and APR-Apprenticeship. Omitted education dummy is TERT-technical schooling, such as medical or teaching or other vocational schooling. Estimates include dummies for region of graduation. Region Switch is a dummy to indicate those who reside in different region relative to graduation date. Standard errors in parentheses clustered on region of graduation. Estimates weighted with enumeration weights. R. Grad Urate variables are instrumented with R14 Mod Urate (UNI $\mid$ TERT | APR) variables, the unemployment rates specific to each of the three education levels in the region where an individual resided at age 14 at the modal graduation year for their age cohort following Kahn (2010). Model is just-identified. Multivariate $F(\mathrm{AP})$ is the F-test for joint significance of instruments from Angrist and Pischke (2009). ${ }^{* * *} \mathrm{p}<0.01,{ }^{* *}$ $\mathrm{p}<0.05,{ }^{*} \mathrm{p}<0.1$ for all coefficients and test statistics. 
TABLE A4: Robustness check: IV impacts on overeducation measures, comparing actual to modal education

\begin{tabular}{|c|c|c|c|c|}
\hline Second Stage & \begin{tabular}{l}
\multicolumn{1}{c}{$(1)$} \\
Pr(OE) \\
Mode \\
OCC
\end{tabular} & \begin{tabular}{l}
\multicolumn{1}{c}{$(2)$} \\
Pr(OE) \\
Mode \\
IND
\end{tabular} & $\begin{array}{l}\quad(3) \\
\text { Distance } \\
\text { Mode } \\
\text { OCC }\end{array}$ & $\begin{array}{l}\quad(4)) \\
\text { Distance } \\
\text { Mode } \\
\text { IND }\end{array}$ \\
\hline R. Grad Urate (UNI) & $\begin{array}{l}0.001 \\
(0.007)\end{array}$ & $\begin{array}{l}0.012 * * \\
(0.005)\end{array}$ & $\begin{array}{l}0.049 * \\
(0.026)\end{array}$ & $\begin{array}{l}0.140 * * * \\
(0.048)\end{array}$ \\
\hline R. Grad Urate (TERT) & $\begin{array}{l}-0.004 \\
(0.008)\end{array}$ & $\begin{array}{l}0.003 \\
(0.010)\end{array}$ & $\begin{array}{l}0.014 \\
(0.017)\end{array}$ & $\begin{array}{l}0.116^{* * *} \\
(0.043)\end{array}$ \\
\hline R Grad Urate (APR) & $\begin{array}{l}0.017 * * \\
(0.007)\end{array}$ & $\begin{array}{l}0.008 \\
(0.006)\end{array}$ & $\begin{array}{l}0.043^{*} \\
(0.022)\end{array}$ & $\begin{array}{l}0.037 \\
(0.026)\end{array}$ \\
\hline University & $\begin{array}{l}-0.279 * * * \\
(0.083)\end{array}$ & $\begin{array}{l}-0.082 \\
(0.113)\end{array}$ & $\begin{array}{l}-0.241 \\
(0.379)\end{array}$ & $\begin{array}{l}1.652 * * * \\
(0.564)\end{array}$ \\
\hline Apprentice & $\begin{array}{l}-0.287 * * * \\
(0.103)\end{array}$ & $\begin{array}{l}-0.167 \\
(0.126)\end{array}$ & $\begin{array}{l}-0.227 \\
(0.370)\end{array}$ & $\begin{array}{l}0.460 \\
(0.609)\end{array}$ \\
\hline Age & $\begin{array}{l}0.041 * * * \\
(0.013)\end{array}$ & $\begin{array}{l}0.035^{* * *} \\
(0.010)\end{array}$ & $\begin{array}{l}0.369 * * * \\
(0.057)\end{array}$ & $\begin{array}{l}0.413 * * * \\
(0.062)\end{array}$ \\
\hline $\mathrm{Age}^{2}$ & $\begin{array}{l}-0.001 * * \\
(0.000)\end{array}$ & $\begin{array}{l}-0.000 * * \\
(0.000)\end{array}$ & $\begin{array}{l}-0.005^{* * *} \\
(0.001)\end{array}$ & $\begin{array}{l}-0.005^{* * * *} \\
(0.001)\end{array}$ \\
\hline Married & $\begin{array}{l}-0.039^{*} \\
(0.021)\end{array}$ & $\begin{array}{l}-0.036^{*} \\
(0.018)\end{array}$ & $\begin{array}{l}-0.443 * * * \\
(0.099)\end{array}$ & $\begin{array}{l}-0.365^{* * *} \\
(0.142)\end{array}$ \\
\hline Male & $\begin{array}{l}-0.011 \\
(0.015)\end{array}$ & $\begin{array}{l}0.093 * * * \\
(0.021)\end{array}$ & $\begin{array}{l}-0.253 * * * \\
(0.065)\end{array}$ & $\begin{array}{l}0.336 * * * \\
(0.108)\end{array}$ \\
\hline German & $\begin{array}{l}-0.058^{* *} \\
(0.025)\end{array}$ & $\begin{array}{l}-0.016 \\
(0.061)\end{array}$ & $\begin{array}{l}0.073 \\
(0.188)\end{array}$ & $\begin{array}{l}-0.008 \\
(0.239)\end{array}$ \\
\hline Region Switch & $\begin{array}{l}0.020 \\
(0.036)\end{array}$ & $\begin{array}{l}0.016 \\
(0.036)\end{array}$ & $\begin{array}{l}0.221 \\
(0.182)\end{array}$ & $\begin{array}{l}0.096 \\
(0.212)\end{array}$ \\
\hline \multicolumn{5}{|l|}{ First Stage - UNI } \\
\hline R. Grad Urate 14 (UNI) & $\begin{array}{l}0.927 * * * \\
(0.012)\end{array}$ & $\begin{array}{l}0.928 * * * \\
(0.012)\end{array}$ & $\begin{array}{l}0.927 * * * \\
(0.012)\end{array}$ & $\begin{array}{l}0.928 * * * \\
(0.013)\end{array}$ \\
\hline Multivariate $F(\mathrm{AP})$ & $14069.3 * * *$ & $12096.4 * * *$ & $11976.0 * * *$ & $10457.04 * * *$ \\
\hline \multicolumn{5}{|l|}{ First Stage - TERT } \\
\hline R. Grad Urate 14 (TERT) & $\begin{array}{l}0.967 * * * \\
(0.006)\end{array}$ & $\begin{array}{l}0.968^{* * * *} \\
(0.006)\end{array}$ & $\begin{array}{l}0.968 * * * \\
(0.007)\end{array}$ & $\begin{array}{l}0.969^{* * *} \\
(0.006)\end{array}$ \\
\hline Multivariate $F$ (AP) & $36880.4 * * *$ & $31162.1 * * *$ & $33934.4 * * *$ & $29461.4 * * *$ \\
\hline \multicolumn{5}{|l|}{ First Stage - APR } \\
\hline R. Grad Urate 14 (APR) & $\begin{array}{l}0.962 * * * \\
(0.003)\end{array}$ & $\begin{array}{l}0.962 * * * \\
(0.004)\end{array}$ & $\begin{array}{l}0.964 * * * \\
(0.003)\end{array}$ & $\begin{array}{l}0.963 * * * \\
(0.004)\end{array}$ \\
\hline Multivariate $F(\mathrm{AP})$ & $1.4 \mathrm{e}^{5 * * *}$ & $1.0 \mathrm{e}^{5 * * *}$ & $1.3 \mathrm{e}^{5 * * *}$ & $97052.9 * * *$ \\
\hline $\mathrm{N}$ & 13,771 & 14,122 & 12,987 & 13,313 \\
\hline $\mathrm{R}_{-}{ }^{2}$ & 0.027 & 0.073 & 0.036 & 0.223 \\
\hline
\end{tabular}

Source: GSOEP 1994-2012. Regional unemployment rates exclude self-employed and pool the effects of graduation timing across all individuals using their highest achieved education level. Education levels: UNI-university and APR-Apprenticeship. Omitted education dummy is TERT-technical schooling, such as medical or teaching or other vocational schooling. Estimates include dummies for region of graduation. Region Switch is a dummy to indicate those who reside in different region relative to graduation date. Standard errors in parentheses clustered on region of graduation. Estimates weighted with enumeration weights. R. Grad Urate variables are instrumented with R14 Mod Urate (UNI | TERT | APR) variables, the unemployment rates specific to each of the three education levels in the region where an individual resided at age 14 at the modal graduation year for their age cohort following Kahn (2010). Model is just-identified. Multivariate $F(\mathrm{AP})$ is the F-test for joint significance of instruments from Angrist and Pischke (2009). ${ }^{* * *} \mathrm{p}<0.01,{ }^{* *}$ $\mathrm{p}<0.05,{ }^{*} \mathrm{p}<0.1$ for all coefficients and test statistics. Overeducated if years of education $>$ highest modal education for year and occupation/industry. 
TABLE A5: Robustness Check: OLS results conditional on match quality in the first ever job

\begin{tabular}{llllll}
\hline & $(1)$ & $(2)$ & $(3)$ & $(4)$ & $(5)$ \\
& $\begin{array}{l}\text { Pr(OE) } \\
\text { Median } \\
\text { OCC }\end{array}$ & $\begin{array}{l}\text { Pr(OE) } \\
\text { Median } \\
\text { IND }\end{array}$ & $\begin{array}{l}\text { Distance } \\
\text { Median } \\
\text { OCC }\end{array}$ & $\begin{array}{l}\text { Distance } \\
\text { Median } \\
\text { IND }\end{array}$ & $\begin{array}{l}\text { Pr(Work in } \\
\text { the OCC was } \\
\text { Trained For) }\end{array}$ \\
\hline R. Grad Urate & $0.011^{*}$ & $0.011^{* * *}$ & 0.032 & $0.060^{* * *}$ & 0.006 \\
& $(0.006)$ & $(0.003)$ & $(0.025)$ & $(0.019)$ & $(0.007)$ \\
Overed. in First & $0.382^{* * *}$ & & $1.900^{* * *}$ & & \\
Job (OCC) & $(0.045)$ & & $(0.217)$ & & \\
Overed. in First & & $0.451^{* * *}$ & & $2.090^{* * *}$ & \\
Job (IND) & & $(0.041)$ & & $(0.200)$ & \\
First job is Occ & & & & & $0.336 * * *$ \\
Trained For & & & & & $(0.069)$ \\
\hline $\mathrm{N}$ & 6,177 & 6,170 & 6,177 & 6,170 & 1,045 \\
$\mathrm{R}^{2}$ & 0.165 & 0.431 & 0.218 & 0.508 & 0.223 \\
\hline
\end{tabular}

Source: GSOEP 1994-2012. Regional unemployment rates exclude self-employed and pool the effects of graduation timing across all individuals using their highest achieved education level. Overeducated in first job is the binary overeducation status for those observed in their initial job after graduation. The particular measure used corresponds to dependent variable. Controls include Education dummies for university, other tertiary and apprenticeship schooling, region of graduation, region switch dummy quadratics in age and experience, dummies for gender, marital status and german nationality. Standard errors in parentheses clustered on region of graduation. Estimates weighted with enumeration weights. ${ }^{* * *} \mathrm{p}<0.01,{ }^{* *} \mathrm{p}<0.05$, ${ }^{*}$ $\mathrm{p}<0.1$ for all coefficients and test statistics. 
TABLE A6: The marginal effect of labour market entry conditions on overeducation by grouped years since graduation

\begin{tabular}{|c|c|c|c|c|c|}
\hline $\begin{array}{c}\text { Years } \\
\text { Since } \\
\text { Graduation }\end{array}$ & $\begin{array}{l}(1) \\
\text { Pr(OE) } \\
\text { Median } \\
\text { OCC }\end{array}$ & $\begin{array}{l}(2) \\
\text { Pr(OE) } \\
\text { Median } \\
\text { IND }\end{array}$ & $\begin{array}{l}\quad(3) \\
\text { Distance } \\
\text { Median } \\
\text { OCC }\end{array}$ & $\begin{array}{l}\quad(4) \\
\text { Distance } \\
\text { Median } \\
\text { IND }\end{array}$ & $\begin{array}{l}(5) \\
\text { Pr(Work in } \\
\text { the OCC was } \\
\text { Trained For) }\end{array}$ \\
\hline \multicolumn{6}{|c|}{ All Schooling Types } \\
\hline 0 & $\begin{array}{l}0.011^{* *} \\
(0.004)\end{array}$ & $\begin{array}{c}0.005 \\
(0.006)\end{array}$ & $\begin{array}{c}0.020 \\
(0.022)\end{array}$ & $\begin{array}{c}0.025 \\
(0.025)\end{array}$ & $\begin{array}{l}-0.016 \\
(0.009)\end{array}$ \\
\hline $1-3$ & $\begin{array}{c}0.008 \\
(0.005)\end{array}$ & $\begin{array}{l}0.011^{* *} \\
(0.005)\end{array}$ & $\begin{array}{c}0.024 \\
(0.025)\end{array}$ & $\begin{array}{c}0.067 * \\
(0.026)\end{array}$ & $\begin{array}{c}0.001 \\
(0.005)\end{array}$ \\
\hline $4-6$ & $\begin{array}{l}0.014 * * \\
(0.006)\end{array}$ & $\begin{array}{l}0.012 * * \\
(0.005)\end{array}$ & $\begin{array}{c}0.043^{*} \\
(0.023)\end{array}$ & $\begin{array}{l}0.070 * * * \\
(0.022)\end{array}$ & $\begin{array}{c}0.006 \\
(0.005)\end{array}$ \\
\hline $5-9$ & $\begin{array}{c}0.013 \\
(0.009)\end{array}$ & $\begin{array}{c}0.007 \\
(0.006)\end{array}$ & $\begin{array}{c}0.057^{*} \\
(0.029)\end{array}$ & $\begin{array}{l}0.071 * * \\
(0.033)\end{array}$ & $\begin{array}{c}0.002 \\
(0.006)\end{array}$ \\
\hline $10-12$ & $\begin{array}{c}0.011 \\
(0.008)\end{array}$ & $\begin{array}{c}0.009 \\
(0.008)\end{array}$ & $\begin{array}{c}0.066^{*} \\
(0.036)\end{array}$ & $\begin{array}{c}0.058 \\
(0.034)\end{array}$ & $\begin{array}{l}-0.0003 \\
(0.006)\end{array}$ \\
\hline $13-15$ & $\begin{array}{c}0.002 \\
(0.008)\end{array}$ & $\begin{array}{c}0.009 \\
(0.007)\end{array}$ & $\begin{array}{c}0.048 \\
(0.042)\end{array}$ & $\begin{array}{c}0.021 \\
(0.051)\end{array}$ & $\begin{array}{c}0.003 \\
(0.010)\end{array}$ \\
\hline $16-18$ & $\begin{array}{c}0.020 \\
(0.015) \\
\end{array}$ & $\begin{array}{c}0.003 \\
(0.010) \\
\end{array}$ & $\begin{array}{l}0.107 \\
(0.087)\end{array}$ & $\begin{array}{c}0.046 \\
(0.061) \\
\end{array}$ & $\begin{array}{l}-0.011 \\
(0.023) \\
\end{array}$ \\
\hline \multicolumn{6}{|c|}{ University Only } \\
\hline 0 & $\begin{array}{c}0.003 \\
(0.007)\end{array}$ & $\begin{array}{l}-0.018 * * \\
(0.006)\end{array}$ & $\begin{array}{l}-0.029 \\
(0.030)\end{array}$ & $\begin{array}{l}-0.078 * * \\
(0.034)\end{array}$ & $\begin{array}{l}-0.028 * * * \\
(0.005)\end{array}$ \\
\hline $1-3$ & $\begin{array}{c}0.0002 \\
(0.005)\end{array}$ & $\begin{array}{c}0.007 * \\
(0.004)\end{array}$ & $\begin{array}{l}-0.024 \\
(0.017)\end{array}$ & $\begin{array}{c}0.028 \\
(0.027)\end{array}$ & $\begin{array}{l}-0.001 \\
(0.005)\end{array}$ \\
\hline $4-6$ & $\begin{array}{c}0.009 \\
(0.006)\end{array}$ & $\begin{array}{l}0.020 * * * \\
(0.003)\end{array}$ & $\begin{array}{c}0.009 \\
(0.023)\end{array}$ & $\begin{array}{l}0.071 * * * \\
(0.022)\end{array}$ & $\begin{array}{c}0.010^{*} \\
(0.005)\end{array}$ \\
\hline $5-9$ & $\begin{array}{c}0.014 \\
(0.009)\end{array}$ & $\begin{array}{l}0.026^{* * * *} \\
(0.005)\end{array}$ & $\begin{array}{c}0.039 \\
(0.041)\end{array}$ & $\begin{array}{c}0.113 * * \\
(0.030)\end{array}$ & $\begin{array}{c}0.012 * \\
(0.006)\end{array}$ \\
\hline $10-12$ & $\begin{array}{c}0.017 \\
(0.010)\end{array}$ & $\begin{array}{l}0.025 * * * \\
(0.006)\end{array}$ & $\begin{array}{c}0.047 \\
(0.045)\end{array}$ & $\begin{array}{l}0.100 * * \\
(0.044)\end{array}$ & $\begin{array}{c}0.015^{*} \\
(0.006)\end{array}$ \\
\hline $13-15$ & $\begin{array}{c}0.031 * \\
(0.014)\end{array}$ & $\begin{array}{l}0.031^{* *} \\
(0.011)\end{array}$ & $\begin{array}{l}0.117^{*} \\
(0.060\end{array}$ & $\begin{array}{l}0.182 * * \\
(0.068)\end{array}$ & $\begin{array}{c}0.011 \\
(0.014)\end{array}$ \\
\hline $16-18$ & $\begin{array}{l}0.028 \\
(0.022) \\
\end{array}$ & $\begin{array}{c}0.032 \\
(0.019)\end{array}$ & $\begin{array}{c}0.140 \\
(0.121)\end{array}$ & $\begin{array}{r}0.258^{*} \\
(0.134) \\
\end{array}$ & $\begin{array}{l}-0.009 \\
(0.030)\end{array}$ \\
\hline $\mathrm{N}$ & 12982 & 13286 & 12982 & 13286 & 12359 \\
\hline
\end{tabular}

Source: GSOEP 1994-2012. Marginal effects from OLS regressions including dummies for grouped years since graduation, the regional unemployment rate at graduation and their interactions, and a full set of average regional unemployment rates at the three year intervals. All Schooling types from regressions with pooled unemployment rates from all post-secondary graduates. University only marginal effects calculated for university graduates from regressions with unemployment rates split by education type. Regional unemployment rates exclude self-employed. Other control variables include education levels: UNI-university, TERT-technical schooling such as medical or teaching or other vocational schooling, APR-

Apprenticeship, dummies for region of graduation, dummies for German nationality, gender and marital status, and age in years and its quadratic. Restricted to those who do not switch region since graduation. Standard errors in parentheses clustered on region of graduation. Estimates weighted with enumeration weights. 
FIGURE A1: The effect of labour market entry conditions on overeducation by years since graduation: All graduates
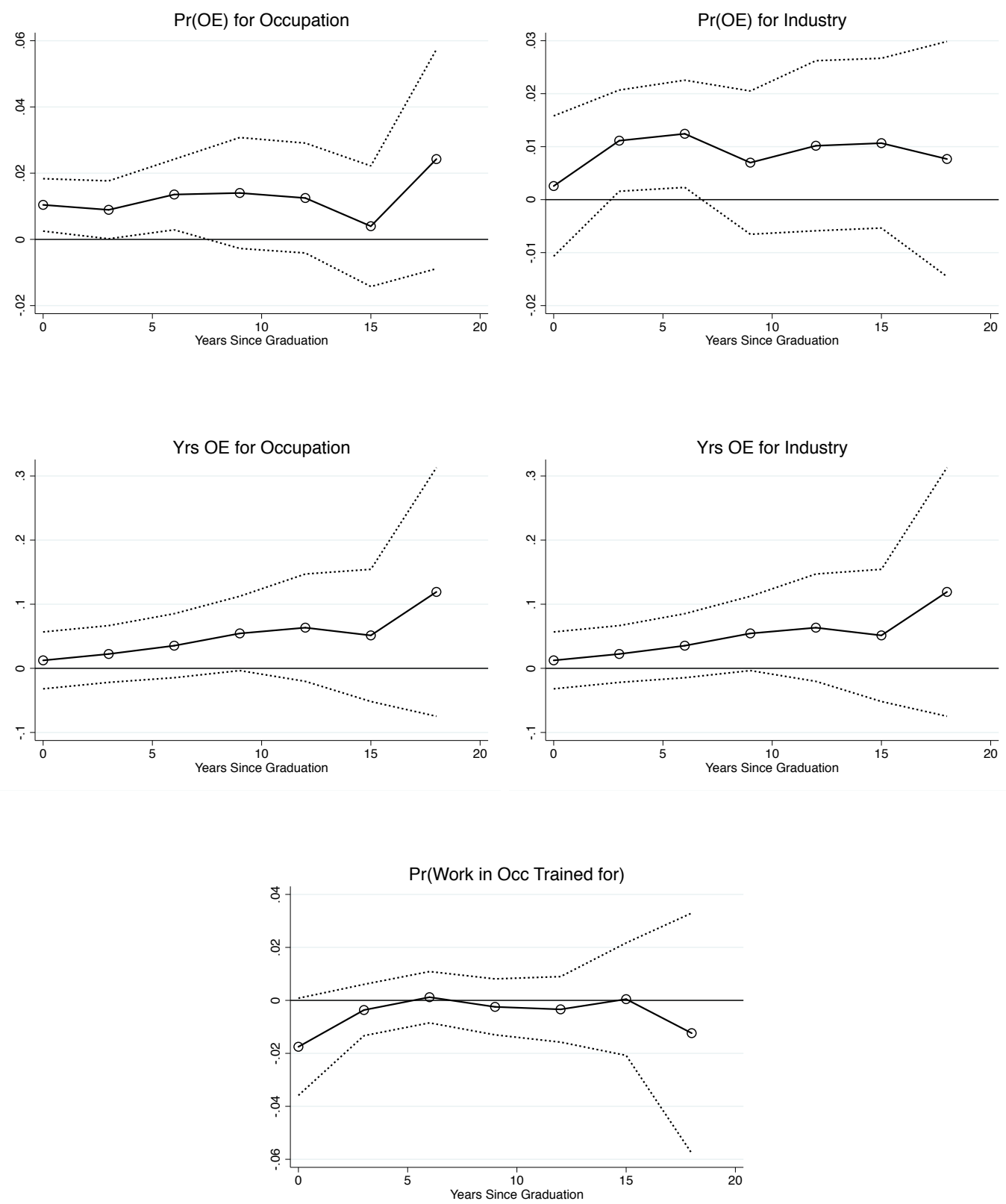

Plots are the marginal effects of regional unemployment rates at graduation on measures of education mismatch, evaluated at three year intervals since the year of graduation. Coefficient estimates provided in the top panel of Table 6 . Dashed lines represent $95 \%$ confidence intervals. 
FIGURE A2: The effect of labour market entry conditions on overeducation by years since graduation: University graduates
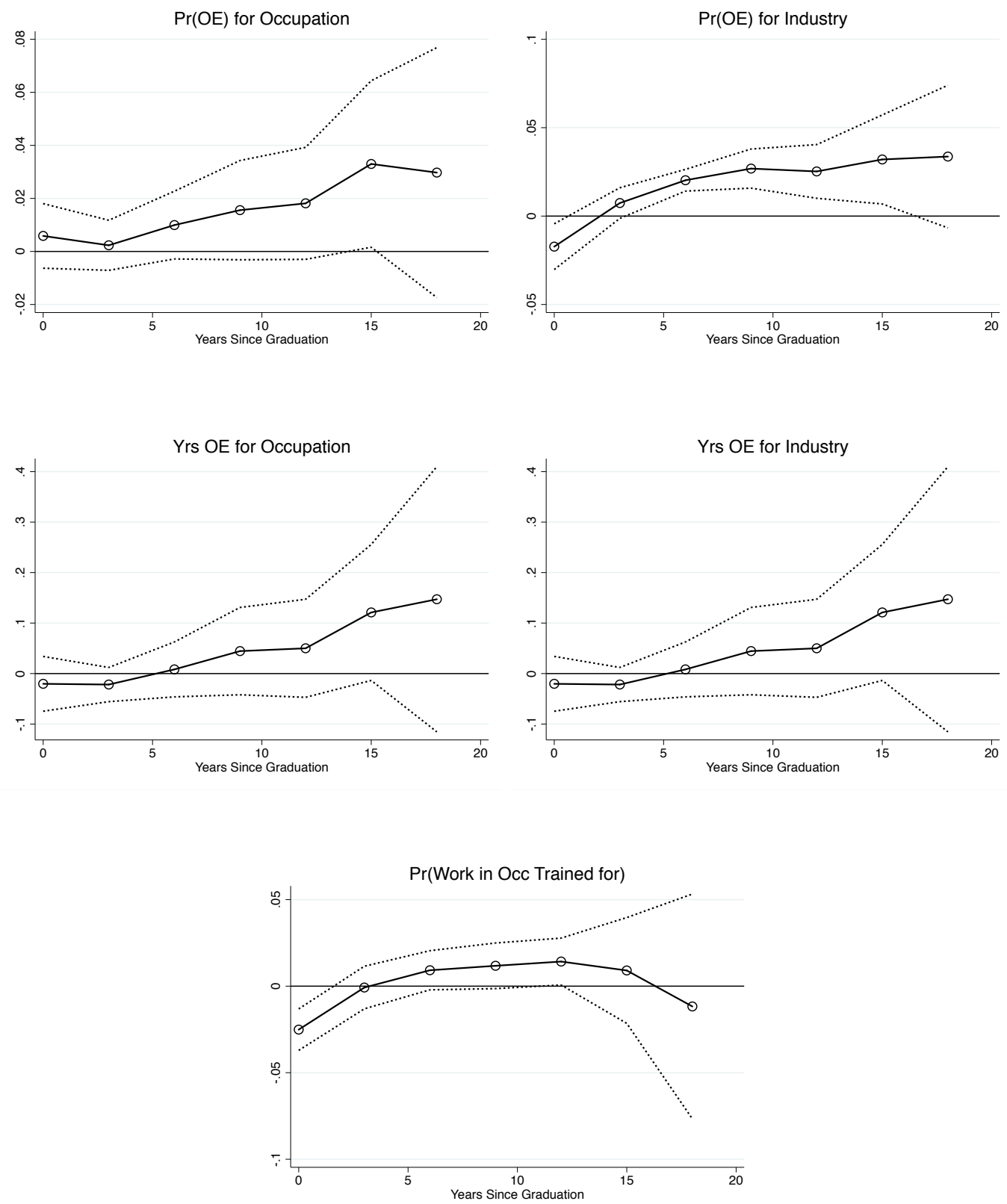

Plots are the marginal effects of regional unemployment rates at graduation on measures of education mismatch, evaluated at three year intervals since the year of graduation. Coefficient estimates provided in the bottom panel of Table 6. Dashed lines represent $95 \%$ confidence intervals. 